Estudios Constitucionales, Año 11, No 1, 2013, pp. 275 - 332.

ISSN 0718-0195

Centro de Estudios Constitucionales de Chile Universidad de Talca

"Un estudio sobre el cumplimiento y ejecución de las sentencias de la Corte Interamericana de Derechos Humanos por el Estado de Chile"

Bárbara Ivanschitz Boudeguer

\title{
UN ESTUDIO SOBRE EL CUMPLIMIENTO Y EJECUCIÓN DE LAS SENTENCIAS DE LA CORTE INTERAMERICANA DE DERECHOS HUMANOS POR EL ESTADO DE CHILE*
}

\author{
A STUDY ON COMPLIANCE AND EXECUTION OF \\ THE DECISIONS ADOPTED BY THE INTER-AMERICAN COURT \\ OF HUMAN RIGHTS BY THE STATE OF CHILE
}

\author{
BÁRBARA IVANSCHITZ BOUdEGUER** \\ Profesora de Derecho \\ Universidad del Desarrollo \\ bivanschitz@udd.cl
}

RESUMEN: La presente investigación tiene por objeto analizar los casos en que el Estado de Chile ha sido condenado por la Corte Interamericana de Derechos Humanos, el alcance de los derechos que se estimaron vulnerados, las medidas de reparación impuestas y el estado de cumplimiento de las mismas para, finalmente, determinar las circunstancias o factores que han dificultado o impedido la completa ejecución de las sentencias emanadas de la Corte.

ABSTRACT: This research focuses on the cases when the State of Chile has been convicted by the Inter-American Court of Human Rights, the scope of the rights that have been infringed, the imposed compensation measures and the state of their fulfilment to, finally, determining the circumstances or factors that have stopped or prevented the complete execution of the decisions given by the Court.

PALABRAS CLAVES: Corte Interamericana de Derechos Humanos, Convención Americana de Derechos Humanos, medidas de reparación, supervisión de cumplimiento de sentencias.

KEY WORDS: Inter-American Court of Human Rights, American Convention of Human Rights, compensation measures, decision fulfillment supervision.

\section{INTRODUCCIÓN}

Desde el momento en que el Estado de Chile decide formar parte de la Organización de Estados Americanos, ratificar la Convención Americana de Derechos Humanos (en adelante $\mathrm{CADH}$ ) y reconocer competencia a la Corte Interamericana de Derechos Humanos (en adelante CIDH), limita su soberanía y pasa a

\footnotetext{
* Trabajo recibido el 30 de noviembre de 2012 y aprobado el 20 de marzo de 2013.

** Profesora de Derecho Político de la Facultad de Derecho de la Universidad del Desarrollo. bivanschitz@udd.cl.
} 
convertirse en destinatario de un conjunto de obligaciones internacionales, tales como las de promover, proteger y garantizar los derechos humanos, reconocidos tanto en su legislación interna como en la $\mathrm{CADH}$; adoptar todas las medidas legislativas o de otro carácter necesarias para hacer efectivos tales derechos y dar cumplimiento a las sentencias emanadas de la $\mathrm{CIDH}$ en todos los casos en que sea parte (arts. 1.1, 2 y 63 de la CADH).

$\mathrm{La} \mathrm{CIDH}$ ha conocido de cinco casos contenciosos contra el Estado de Chile y en todos ellos ha establecido la responsabilidad de éste por violación de determinados derechos consagrados en la $\mathrm{CADH}$, imponiéndole el deber de ejecutar acciones internas (de naturaleza legislativa o jurisdiccional) con el objeto de dar cumplimiento a sus obligaciones internacionales, lo cual no siempre resulta sencillo pues, para algunos, ello estaría poniendo en tela de juicio la soberanía estatal, interfiriendo con la actividad de los tribunales nacionales de justicia y eventuales decisiones dictadas por éstos, con efecto de cosa juzgada. Esto presenta un problema aún no resuelto plenamente en nuestro ordenamiento jurídico, cual es el de compatibilizar la competencia de la CIDH con la de los órganos jurisdiccionales nacionales y su facultad de imperio para hacer cumplir sus respectivas resoluciones.

\section{Casos contenciosos del estado de Chile ante la CIDH}

\section{A. Olmedo Bustos y otros vs. Chile: caso "La Última Tentación de Cristo".} Sentencia de 05 de febrero de $2001^{1}$

En este caso la $\mathrm{CIDH}$ estableció que, a través de las resoluciones de los tribunales de justicia, el Estado había violado el derecho a la libertad de pensamiento y expresión, consagrado en el artículo 13 de la $\mathrm{CADH}$, incumpliendo además los deberes generales comprendidos en los artículos 1.1 y 2 de la misma (obligación de respetar y garantizar los derechos reconocidos en la Convención y adoptar medidas para hacerlos efectivos), al consagrar constitucionalmente un sistema de censura previa para la exhibición y publicidad de la producción cinematográfica (artículo 19, número 12, inciso final, de la Constitución Política de la República).

Así, el Consejo de Calificación Cinematográfica rechazó en el año 1988 una solicitud de la empresa "United International Pictures Ltda." para exhibir la pelí-

${ }^{1}$ CIDH, Caso Olmedo Bustos y otros vs. Chile, de 5 de febrero de 2001. 
cula "La Última Tentación de Cristo". Sin embargo, ocho años después, y sobre la base de una nueva solicitud, el mismo Consejo revisó la resolución anterior y autorizó la exhibición de la cinta, decisión que fue recurrida de protección para ante la Corte de Apelaciones de Santiago por un grupo de particulares, actuando en nombre de Jesucristo, la Iglesia Católica y por sí mismos. La Corte acogió la acción de protección en sentencia confirmada por la Excelentísima Corte Suprema de Justicia, la que validó de esta forma la censura previa bajo el argumento de que el ejercicio de la libertad de expresión podía colisionar con el derecho a la honra (en este caso, de Jesucristo), caso en el cual, debía privilegiarse la restricción y no la libertad.

\section{B. Caso Palamara Iribarne Vs. Chile. Sentencia de 22 de noviembre de $2005^{2}$}

La Corte resolvió que el Estado de Chile violó: a) el derecho a al libertad de pensamiento y de expresión, consagrado en el artículo 13 de la $\mathrm{CADH}$, al prohibir la publicación y comercialización del libro "Ética y Servicios de Inteligencia" escrito por Humberto Palamara Iribarne, en el cual se abordaban aspectos relacionados con la inteligencia militar y la necesidad de adecuarla a ciertos parámetros éticos; b) el derecho de propiedad (art. 21.1 y 21.2 CADH), al incautar los ejemplares y borrar los registros electrónicos del libro en cuestión; c) el derecho de protección judicial (art. $25 \mathrm{CADH}$ ); d) el derecho a la libertad personal y ciertas garantías judiciales (arts. $7^{\circ}$ y $8^{\circ} \mathrm{CADH}$ ), al considerar al señor Palamara Iribarne como militar, no obstante la calidad de oficial de marina en retiro y empleado civil a contrata de la Armada de Chile, y haber sido juzgado y condenado por tribunales militares y no por la justicia ordinaria; todo ello en relación con los artículos 1.1 y $2^{\circ}$ de la CADH.

Debido al intento de publicación del libro y a algunas declaraciones del señor Palamara a la prensa, se iniciaron en su contra dos procesos penales; uno por desobediencia e incumplimiento de deberes militares y otro por el delito de desacato. Ambas causas fueron sustanciadas en sede militar en procesos inspirados en principios muy diversos a los que informan el nuevo proceso penal que se estaba implementando a la fecha en el país, pero del que se excluyó expresamente a la justicia militar.

${ }^{2} \mathrm{CIDH}$, Caso Palamara Iribarne vs. Chile, de 22 de noviembre de 2005. 


\section{Claude Reyes y otros vs. Chile. Sentencia de 19 septiembre de $2006^{3}$}

Esta causa versa nuevamente sobre la vulneración del derecho a la libertad de pensamiento y expresión, pero mirado ahora desde el punto de vista del acceso a la información pública, es decir, el derecho a acceder a la información bajo control del Estado.

Los hechos se originaron por la negativa infundada del Estado en orden a proporcionar a las víctimas toda la información que requerían del Comité de Inversiones Extranjeras, en relación con el Proyecto Río Cóndor, de la empresa forestal Trillium Ltda., que era un proyecto de industrialización forestal que generó gran discusión pública por el impacto ambiental que podía tener en la zona sur del país.

Debido a la negativa de información, los interesados recurrieron de protección ante la Corte de Apelaciones de Santiago, fundados en la supuesta violación por parte del Estado de Chile a la libertad de expresión y al derecho de acceso a la información, siendo declarado inadmisible por manifiesta falta de fundamento, sin mayor argumentación.

La CIDH declaró que Chile había violado el derecho a la libertad de pensamiento y expresión al no entregar toda la información requerida, sin justificación alguna, ni demostrar que se trataba en la especie de aquellas restricciones permitidas por la Convención. Declaró, asimismo, vulnerado el derecho a las garantías judiciales y a la protección judicial (artículos 8.1 y 25), todo ello en relación a los artículos 1.1 y $2^{\circ}$ de la CADH.

\section{Almonacid Arellano y otros vs. Chile. Sentencia de 26 de septiembre de $2006^{4}$}

El 16 de septiembre de 1973, el profesor de enseñanza básica Luis Alfredo Almonacid Arellano, fue detenido y ejecutado por miembros de Carabineros de Chile, iniciándose la investigación de los hechos en octubre de 1973, ante el Primer Juzgado del Crimen de Rancagua, bajo la causa Rol No 40.184, la que fue sobreseída temporalmente en septiembre de 1974. En noviembre de 1992 la viuda del señor Almonacid presentó una querella criminal ante el Primer Juzgado del Crimen de Rancagua solicitando la reapertura de la causa. El 31 de agosto de

${ }^{3}$ CIDH, Caso Claude Reyes y otros vs. Chile, de 19 de septiembre de 2006.

${ }^{4} \mathrm{CIDH}$, Caso Almonacid Arellano vs. Chile, de 26 de septiembre de 2006. 
1996 este tribunal sometió a proceso a Manuel Segundo Castro Osorio, como cómplice, y a Raúl Hernán Neveu Cortesi, como autor del delito de homicidio. Sin embargo, pocos meses después, el Fiscal Militar presentó un incidente de competencia ante la Corte Suprema de Justicia la que declaró que el sistema de justicia militar era el competente para seguir conociendo el asunto. En enero de 1997 el Segundo Juzgado Militar de Santiago sobreseyó la causa en aplicación del Decreto Ley No 2.191 (Decreto Ley de Amnistía), sentencia que fue confirmada por la Corte Marcial.

Respecto de la aplicación del Decreto Ley No 2.191, la CIDH señaló que sólo podía pronunciarse respecto a si el Estado infringió o no su deber de adecuar la legislación interna a la Convención con posterioridad a la ratificación de la misma, porque desde ese momento el Estado adquiere la obligación de adecuar su ordenamiento jurídico nacional a los términos de ésta, y no desde el momento de la promulgación del Decreto Ley No 2.191 en el año $1978 .^{5}$

La Corte ya se había pronunciado en materia de amnistía en el caso Barrios Altos señalando que: "son inadmisibles las disposiciones de amnistía, las disposiciones de prescripción y el establecimiento de excluyentes de responsabilidad que pretendan impedir la investigación y sanción de los responsables de las violaciones graves de los derechos humanos tales como la tortura, las ejecuciones sumarias, extralegales o arbitrarias y las desapariciones forzadas, todas ellas prohibidas por contravenir derechos inderogables reconocidos por el Derecho Internacional de los Derechos Humanos". ${ }^{6}$

En el caso contra Chile, la CIDH concluyó que "...dada su naturaleza, el Decreto Ley $N^{o} 2.191$ carece de efectos jurídicos y no puede seguir representando un obstáculo para la investigación de los hechos que constituyen este caso, ni para la identificación y el castigo de los responsables, ni puede tener igual o similar impacto respecto de otros casos de violación de los derechos consagrados en la Convención Americana acontecidos en Chile".

Si bien la Corte reconoció los esfuerzos que ha hecho el Estado en materia de reparaciones por las violaciones a los Derechos Humanos, y que los tribunales nacionales han experimentado un vuelco jurisprudencial dejando de aplicar el Decreto Ley No 2.191, estima que ello no es suficiente, pues al mantener la vigencia de esta ley nada asegura que no vuelva eventualmente a ser aplicada por los tribunales del país.

${ }^{5}$ CIDH, Caso Almonacid Arellano vs. Chile, de 26 de septiembre de 2006 (par. 50).

${ }^{6} \mathrm{CIDH}$, Caso Barrios Altos vs. Perú, de 14 de marzo de 2001 (par. 41).

7 CIDH, Caso Almonacid Arellano vs. Chile, de 26 de septiembre de 2006 (par. 50). 
Por lo anterior, la CIDH concluyó que el Estado vulneró los artículos 25 y 8.1 de la $\mathrm{CADH}$, pues sustrajo el conocimiento del asunto desde el juez natural hacia la jurisdicción militar, la cual no cumplía con los estándares de competencia, independencia e imparcialidad necesarias. También declaró que el Estado incumplió las obligaciones derivadas de los artículos 1.1 y 20 de la Convención al mantener vigente el Decreto Ley No 2.191 que permite la aplicación de la amnistía a crímenes que la CIDH calificó de lesa humanidad, norma que claramente es contraria a la $\mathrm{CADH}$.

\section{E. Atala Riffo y Niñas vs. Chile. Sentencia de 24 de febrero de $2012^{8}$}

Éste es el primer caso en que la Corte se pronuncia sobre el derecho a la igualdad y prohibición de discriminación, en materia de orientación sexual.

La causa se origina en un juicio de tuición en que el padre de tres menores demandaba para sí el cuidado de éstas, fundando en que la orientación sexual de la madre y su convivencia con una pareja del mismo sexo producirían un daño a las niñas.

La Corte Suprema de Justicia, conociendo de un recurso de queja deducido por el padre, revocó la sentencia que confería la tuición de las menores a la madre argumentado que la condición homosexual de la madre podría causar un daño en las menores.

De esta decisión se recurrió ante la Comisión Interamericana de Derechos Humanos, la que demandó al Estado ante la CIDH, en septiembre de 2010. El objeto de este caso no era dirimir cuál de los padres ofrecía un mejor hogar para las menores, sino determinar si en el juicio de tuición iniciado por el padre de las niñas y en el proceso disciplinario llevado a cabo en contra de la señora Karen Atala Riffo (jueza de la República) se habían vulnerado algunos de los derechos reconocidos y amparados por la $\mathrm{CADH}$. En efecto, la $\mathrm{CIDH}$ reiteró que la jurisdicción internacional tiene carácter subsidiario, coadyuvante y complementario. No constituye un tribunal de cuarta instancia. ${ }^{?}$

La Corte declaró responsable al Estado fundamentalmente por violación del derecho a la igualdad y no discriminación consagrado en el artículo 24, en relación con el artículo 1.1 de la CADH.

${ }^{8}$ CIDH, Caso Atala Riffo y Niñas vs. Chile, de 24 de febrero de 2012.

9 CIDH, Caso Atala Riffo y Niñas vs. Chile, de 24 de febrero de 2012 (par. 65). 


\section{Consideraciones SObre los Derechos que EN ESTOS CINCO Casos HAN SIDO VULNERADOS POR EL ESTADO DE CHILE}

La CIDH ha ido delimitando en sus sentencias los alcances y contenidos de los derechos consagrados en la CADH lo cual resulta de suyo importante para orientar la interpretación y aplicación que de los mismos deben hacer los tribunales nacionales y los demás órganos del Estado, a fin de no hacer incurrir al Estado nuevamente en responsabilidad internacional por la vulneración de éstos. Así, estas sentencias han permitido orientar las reformas constitucionales y legales que han sido necesarias para adecuar el ordenamiento jurídico interno a los estándares internacionales.

Me referiré a continuación a algunos de estos derechos, su contenido y alcances.

\section{A. Derecho a la Libertad de Pensamiento y Expresión}

El Estado de Chile ha sido condenado en tres oportunidades ${ }^{10}$ por violación a este derecho, el cual, como lo ha señalado la Corte, comprende tanto el derecho a difundir información, como el derecho a recibirla (art. 13.1). Por su parte, el art. 13.2 de la CADH establece la prohibición de limitar el ejercicio de este derecho mediante censura previa. El ejercicio de la libertad de expresión sólo admite las restricciones que expresamente regula la Convención.

En el caso de la película "La Última Tentación de Cristo" la Corte constató la disconformidad del ordenamiento jurídico nacional con los estándares internacionales en esta materia, al consagrar constitucionalmente un sistema de censura previa para la exhibición y publicidad de la producción cinematográfica.

En el caso Palamara Iribarne, la Corte tuvo la oportunidad de pronunciarse de manera más extensa sobre otro aspecto del derecho a la libertad de pensamiento y expresión, cual es el relativo a las restricciones al ejercicio de este derecho.

La Corte ha precisado que éste no es un derecho absoluto, pues el artículo 13.2 consagra la posibilidad de establecer restricciones a través de la aplicación de responsabilidades ulteriores por el ejercicio abusivo de este derecho. Sin embargo, estas causales de responsabilidad ulterior deben estar expresa, taxativa y previamente fijadas por la ley y, además, ser necesarias para asegurar "el respeto a los derechos o a la reputación de los demás" o "la protección de la seguridad nacional, el orden

$10 \mathrm{CIDH}$, Caso Olmedo Bustos y otros vs. Chile, de 5 de febrero de 2001; Caso Palamara Iribarne vs. Chile, de 22 de noviembre de 2005; Caso Claude Reyes y otros vs. Chile, de 19 de septiembre de 2006. 
público o la salud o la moral públicas" y no deben, de modo alguno, limitar más allá de lo estrictamente necesario el alcance pleno de la libertad de expresión y convertirse en un mecanismo directo o indirecto de censura previa. ${ }^{11}$

Por otro lado, la $\mathrm{CIDH}$ ha señalado que el Derecho Penal es el medio más restrictivo y severo para establecer responsabilidades respecto de una conducta ilícita ${ }^{12}$ y estableció que la legislación penal chilena no se adecuaba a la CADH al tipificar y sancionar en forma agravada el "delito de desacato", el cual se configura al ejecutar hechos o proferir expresiones desdorosas o injuriosas contra órganos en los que radica el poder estatal y contra ciertas autoridades públicas (artículos 263 y siguientes del Código Penal).

"88. ... La Corte considera que la legislación sobre desacato aplicada al señor Palamara Iribarne establecía sanciones desproporcionadas por realizar criticas sobre el funcionamiento de las instituciones estatales y sus miembros, suprimiendo el debate esencial para el funcionamiento de un sistema verdaderamente democrático y restringiendo innecesariamente el derecho a la libertad de pensamiento y de expresión". ${ }^{13}$

Tratándose de funcionarios públicos, políticos e instituciones estatales, se debe aplicar un umbral diferente de protección, el cual no se funda en la calidad del sujeto, sino en el interés público que conllevan las actuaciones de una persona determinada, lo cual implica una mayor tolerancia y apertura a la crítica frente a afirmaciones y apreciaciones formuladas por las personas que ejercen el control democrático. ${ }^{14}$

En el caso "Claude Reyes y otros vs. Chile" se analizó el derecho consagrado en el artículo 13 de la $\mathrm{CADH}$, ya no en su dimensión particular de "derecho a informar", sino en su dimensión colectiva como "derecho de acceso a la información". En efecto, y de acuerdo al alcance que la jurisprudencia de la CIDH ha dado a este derecho, la libertad de pensamiento y expresión comprende no sólo el derecho y libertad a expresar el propio pensamiento sino también el derecho positivo a buscar, recibir y difundir informaciones e ideas de toda índole como sería, por ejemplo, la información bajo el control del Estado. De esta manera, se consagra en este artículo el derecho de las personas a acceder a la información

${ }^{11} \mathrm{CIDH}$, Caso Palamara Iribarne vs. Chile, de 22 de noviembre de 2005 (par. 79).

12 CIDH, Caso Palamara Iribarne vs. Chile, de 22 de noviembre de 2005 (par. 79).

${ }^{13} \mathrm{CIDH}$, Caso Palamara Iribarne vs. Chile, de 22 de noviembre de 2005 (par. 88).

${ }^{14} \mathrm{CIDH}$, Caso Palamara Iribarne vs. Chile, de 22 de noviembre de 2005 (par. 84). 
pública y la obligación del Estado de proporcionarla con las excepciones que la propia Convención autoriza.

La CIDH destacó, asimismo, el carácter individual y social de este derecho y la importancia de su reconocimiento y protección por parte de los Estados ${ }^{15}$, pues el ejercicio de este derecho permitiría una mayor transparencia de las actividades gubernamentales, la cual constituye un componente fundamental del ejercicio de la democracia.

Por último, la CIDH precisó que si bien el derecho de acceso a la información bajo el control del Estado admite restricciones, éstas deben cumplir ciertos requisitos a fin de no afectar el derecho más allá de lo estrictamente necesario. Así, una restricción a este derecho: a) sólo podría ser establecida por ley; b) atender a algunos de los objetivos expresamente señalados en el Convención, esto es, el respeto a los derechos o a la reputación de los demás o la protección de la seguridad nacional, el orden público o la salud o la moral públicas; c) ser necesaria en una sociedad democrática, es decir, estar orientadas a satisfacer un interés público imperativo, y d) cumplir con el criterio de proporcionalidad, es decir, ajustarse al interés que la justifica y ser conducente para obtener el logro del objetivo perseguido, interfiriendo en la menor medida posible en el efectivo ejercicio del derecho.

En este caso en concreto la CIDH resolvió que el Estado de Chile violó el derecho a la libertad de pensamiento y de expresión al no entregar toda la información requerida, sin justificar la negativa ni demostrar que se trataba en la especie de una restricción de aquéllas permitidas por la Convención.

\section{B. Derecho a las garantías Judiciales}

Chile ha sido condenado por la vulneración de varias de las garantías judiciales consagradas en el artículo $8^{\circ}$ de la CADH y que se analizan a continuación.

\section{ral) \\ a) Derecho a ser oido por un juez o tribunal competente (derecho al juez natu-}

En los casos Palamara Iribarne y Almonacid Arellano se condenó al Estado de Chile por vulnerar esta garantía al sustraer el conocimiento del asunto respectivo desde la justicia ordinaria hacia la jurisdicción militar.

La CIDH ha señalado que: "En un Estado democrático de derecho la jurisdicción penal militar ha de tener un alcance restrictivo y excepcional y estar encaminada a

15 CIDH, Caso Claude Reyes y otros vs. Chile, de 19 de septiembre de 2006 (par. 76-78). 
la protección de intereses jurídicos especiales, vinculados con las funciones que la ley asigna a las fuerzas militares. Por ello, sólo se debe juzgar a militares por la comisión de delitos o faltas que por su propia naturaleza atenten contra bienes jurídicos propios del orden militar", 16 agregando que: "cuando la justicia militar asume competencia sobre un asunto que debe conocer la justicia ordinaria, se ve afectado el derecho al juez natural y, a fortiori, el debido proceso, el cual, a su vez, se encuentra intimamente ligado al propio derecho de acceso a la justicia". ${ }^{17}$

La Corte observó que la legislación chilena se aleja bastante de los estándares internacionales en materia de jurisdicción militar, debido a la amplitud de la competencia de los tribunales militares, fundamentalmente por dos factores: a) por la definición de delitos militares y la remisión a diversas leyes que otorgan competencia a los tribunales militares, y b) por la calidad de sujeto activo de los delitos militares y que civiles sean juzgados en sede castrense. Esta objeción fue materia de una reforma en el año 2011.

b) Derecho a ser oido por un tribunal independiente e imparcial

En relación con el caso Palamara Iribarne, la Corte estableció que "la estructura orgánica y composición de los tribunales militares... supone que, en general, sus integrantes sean militares en servicio activo, estén subordinados jerárquicamente a los superiores a través de la cadena de mando, su nombramiento no depende de su competencia profesional e idoneidad para ejercer las funciones judiciales, no cuenten con garantías suficientes de inamovilidad y no posean una formación jurídica exigible para desempeñar el cargo de juez o fiscales. Todo ello conlleva a que dichos tribunales carezcan de independencia e imparcialidad'. ${ }^{18}$

La crítica a la falta de independencia e imparcialidad de la justicia militar es reiterada en el caso Almonacid Arellano. ${ }^{19}$

La Corte consideró especialmente el hecho de que en la época en que ocurrieron los hechos se estaba implementando una importante reforma al procedimiento penal destinada a introducir las garantías del debido proceso en el sistema de enjuiciamiento criminal excluyéndose, sin embargo, de dicha reforma, a la justicia militar.

${ }_{16}$ CIDH, Caso Palamara Iribarne vs. Chile, de 22 de noviembre de 2005 (par. 124); CIDH, Caso Almonacid Arellano vs. Chile, de 26 de septiembre de 2006 (par. 131).

${ }_{17}$ CIDH, Caso Palamara Iribarne vs. Chile, de 22 de noviembre de 2005 (par. 143); CIDH, Caso Almonacid Arellano vs. Chile, de 26 de septiembre de 2006 (par. 131).

${ }_{18} \mathrm{CIDH}$, Caso Palamara Iribarne vs. Chile, de 22 de noviembre de 2005 (par. 155).

$19 \mathrm{CIDH}$, Caso Almonacid Arellano vs. Chile, de 26 de septiembre de 2006 (par. 130). 
La Corte observó además que la justicia militar vulnera el derecho a la publicidad del proceso y el derecho a defensa, pues al mantener el secreto en la etapa del sumario se impide tomar conocimiento del curso de la investigación y prepararla en términos eficientes y oportunos.

\section{Derecho a la igualdad y probibición de discriminación}

El artículo 1.1 de la CADH señala que:

"Los Estados Partes en esta Convención se comprometen a respetar los derechos y libertades reconocidos en ella y a garantizar su libre y pleno ejercicio a toda persona que esté sujeta a su jurisdicción, sin discriminación alguna por motivos de raza, color, sexo, idioma, religión, opiniones politicas o de cualquier otra indole, origen nacional o social, posición económica, nacimiento o cualquier otra condición social".

Por su parte, el artículo 24 establece que:

"Todas las personas son iguales ante la ley. En consecuencia, tienen derecho, sin discriminación, a igual protección de la ley".

Si bien, la orientación sexual no aparece mencionada expresamente como un criterio de no discriminación, la CIDH se encarga de establecer que la enumeración contenida en el artículo 1.1 no es taxativa, sino meramente enunciativa. Lo anterior lo demuestra la propia norma al fijar como uno de esos criterios "cualquier otra condición social", criterio abierto que permite la inclusión de otras categorías que no hubieren sido expresamente indicadas.

Señala la Corte que los tratados de derechos humanos son instrumentos vivos, cuya interpretación debe ajustarse a la evolución de los tiempos y a las condiciones de vida actuales, de manera que al interpretar la expresión "cualquier otra condición social' del artículo 1.1, debe siempre elegirse la alternativa más favorable para la tutela de los derechos protegidos por la Convención, según el principio de la norma más favorable al ser humano. ${ }^{20}$ De esta forma podemos entender incorporado en esa enumeración el criterio de la orientación sexual y la identidad de género de las personas, aun cuando no aparezcan mencionadas de una forma expresa.

Del análisis de los argumentas expuestos por las autoridades judiciales nacionales, así como de sus conductas, el lenguaje utilizado y el contexto en que tales

${ }^{20} \mathrm{CIDH}$, Caso Atala Riffo y Niñas vs. Chile, de 24 de febrero de 2012 (par. 83-84). 
decisiones se adoptaron, la CIDH concluyó que se configuró una diferencia de trato "discriminatoria" fundada en la orientación sexual de la señora Atala, pues se otorgó relevancia significativa a su condición homosexual para la decidir el juicio de tuición de sus hijas. Así, algunos de los fundamentos de la sentencia de la Corte Suprema consideraron la orientación sexual de la señora Atala, a saber: a) la presunta discriminación social que habrían sufrido las menores como consecuencia de la orientación sexual de la madre; b) la alegada confusión de roles que éstas habrían experimentado; c) la supuesta prevalencia que la madre habría dado a su vida personal, y d) el derecho de las niñas a vivir en el seno de un familia tradicional y estructurada normalmente.

Tanto la Corte Suprema de Justicia como el Juzgado de Menores de Villarrica, al otorgar la tuición provisoria al padre, invocaron como argumento para su decisión el interés superior de las menores, pero la CIDH estableció que la determinación del interés superior del niño, en casos de cuidado y custodia de menores de edad, se debe hacer a partir de la evaluación de los comportamientos parentales específicos y su impacto negativo en el bienestar y desarrollo del niño según el caso, los daños o riesgos reales y probados, y no especulativos o imaginarios. Por tanto, no pueden ser admisibles las especulaciones, presunciones, estereotipos o consideraciones generalizadas sobre características personales de los padres o preferencias culturales respecto a ciertos conceptos tradicionales de la familia. ${ }^{21}$

La Corte hizo presente asimismo que el lenguaje empleado por la Corte Suprema en relación con el derecho de las menores a vivir en una familia "estructurada normalmente y apreciada en un medio social" y no en una familia excepcional constituye una concepción estereotipada de familia que no se ajusta a la Convención. En efecto, la Convención no define familia ni se adscribe a un modelo definido de ésta. ${ }^{22}$

Por último, la $\mathrm{CIDH}$ reconoció que la legislación nacional interna no era discriminatoria, sino que la discriminación en este caso se habría producido en sede jurisdiccional. En efecto, el derecho a la igualdad se encuentra garantizado ampliamente en la Constitución Política de la República en los artículos $1^{\circ}, 5^{\circ}$, 19 No 2, 19 No 3, 19 No 17, 19 No 20 y 19 No 22, consagrándose además en el artículo 20 de la misma, una acción de protección para asegurar su amparo de manera eficaz.

${ }^{21}$ CIDH, Caso Atala Riffo y Niñas vs. Chile, de 24 de febrero de 2012 (par. 109).

${ }^{22}$ CIDH, Caso Atala Riffo y Niñas vs. Chile, de 24 de febrero de 2012 (par. 141). 


\section{Medidas de reparación impuestas por la corte al estado de Chile. OBLIGACIÓN DE REPARAR}

Las infracciones por parte de los Estados a los deberes consagrados en los artículos 1.1 y $2^{\circ}$ de la Convención hacen incurrir a éstos en responsabilidad internacional, sin necesidad de que exista falta o culpa por parte de sus órganos y sin necesidad de que se produzca un daño (art. 63.1 CADH).

Así lo estableció la CIDH en el caso "La Última Tentación de Cristo":

"la responsabilidad internacional del Estado puede generarse por actos u omisiones de cualquier poder u órgano de éste, independientemente de su jerarquía, que violen la Convención Americana. Es decir, todo acto u omisión, imputable al Estado, en violación de las normas del Derecho Internacional de los Derechos Humanos, compromete la responsabilidad internacional del Estado". ${ }^{23}$

La CADH no contiene un catálogo de medidas de reparación ni establece parámetros para el establecimiento de éstas. Ha sido la propia $\mathrm{CIDH}$ la que a través de la interpretación sistemática del artículo 63 de la Convención, de los derechos y libertades consagrados en ella y de las obligaciones generales de los Estados (arts. 1.1 y $2^{\circ}$ de la CADH), ha ido estableciendo en sus fallos diversas formas de reparación, las que van mucho más allá de las solas indemnizaciones de perjuicios por el daño experimentado.

En los cinco casos llevados ante la CIDH, ésta ha impuesto a Chile las siguientes medidas de reparación: a) declarar que la propia sentencia constituye per se una forma de reparación ${ }^{24}$; b) publicación de un resumen de la sentencia en el Diario Oficial, en un diario de circulación nacional ${ }^{25}$ e, íntegramente, en el sitio web oficial del Estado ${ }^{26}$; c) indemnización de perjuicios a favor de las víctimas o sus familiares por los daños materiales e inmateriales

23 CIDH, Caso Olmedo Bustos y otros vs. Chile, de 5 de febrero de 2001 (par. 72).

${ }^{24} \mathrm{CIDH}$, Caso Claude Reyes y otros vs. Chile, de 19 de septiembre de 2006 (par. 174, punto 4); CIDH, Caso Palamara Iribarne vs. Chile, de 22 de noviembre de 2005 (par. 269, punto 8); CIDH, Caso Almonacid Arellano vs. Chile, de 26 de septiembre de 2006 (par. 171 punto 4); CIDH, Caso Atala Riffo y Niñas vs. Chile, de 24 de febrero de 2012 (par. 314, punto 1).

${ }_{25}$ CIDH, Caso Claude Reyes y otros vs. Chile, de 19 de septiembre de 2006 (par. 174, punto 6); CIDH, Caso Almonacid Arellano vs. Chile, de 26 de septiembre de 2006 (par. 171 punto 8).

26 CIDH, Caso Palamara Iribarne vs. Chile, de 22 de noviembre de 2005 (par. 269, puntos 10 y 11); CIDH, Caso Atala Riffo y Niñas vs. Chile, de 24 de febrero de 2012 (par. 314, punto 3). 
causados; ${ }^{27}$ d) obligación de pagar los gastos y costas generadas en virtud del proceso respectivo; ${ }^{28}$ e) adecuar el ordenamiento jurídico interno a los estándares internacionales con el fin de suprimir la censura previa, ${ }^{29}$ garantizar la libertad de pensamiento y expresión, ajustar la jurisdicción penal militar a los parámetros internacionales estableciendo límites a la competencia material y personal de los tribunales militares de forma tal que en ninguna circunstancia un civil sea sometido a la jurisdicción militar, ${ }^{30}$ garantizar el derecho de acceso a la información bajo el control del Estado ${ }^{31} y$, asegurar que el Decreto Ley No 2.191 no siga representando un obstáculo para la investigación, juzgamiento $y$, en su caso, sanción de los responsables de graves violaciones a los derechos humanos; $; 2$ f) garantizar el debido proceso en la jurisdicción penal militar y la protección judicial respecto de las actuaciones de las autoridades militares; g) dejar sin efecto, en el plazo de seis meses, las sentencias condenatorias emitidas en contra del señor Humberto Palamara Iribarne en las causas por el delito de desacato por los delitos de desobediencia e incumplimiento de deberes militares, incluyendo la supresión de los antecedentes penales del registro correspondien$\mathrm{te}^{33}$; h) permitir la exhibición de la película "La Última Tentación de Cristo" 34 y la publicación del libro Ética y Servicios de Inteligencia y restituir a su autor todo el material incautado ${ }^{35}$; i) entregar en el plazo de seis meses, a través de la entidad correspondiente, la información solicitada por las víctimas o, en su caso, adoptar una decisión fundamentada al respecto ${ }^{36} ; \mathrm{j}$ ) capacitar, dentro de

27 CIDH, Caso Palamara Iribarne vs. Chile, de 22 de noviembre de 2005 (par. 269, puntos 16-18); CIDH, Caso Atala Riffo y Niñas vs. Chile, de 24 de febrero de 2012 (par. 314, punto 6).

${ }^{28} \mathrm{CIDH}$, Caso Olmedo Bustos y otros vs. Chile, de 5 de febrero de 2001 (par. 103 punto 5); CIDH, Caso Palamara Iribarne vs. Chile, de 22 de noviembre de 2005 (par. 269, punto 18); CIDH, Caso Claude Reyes y otros vs. Chile, de 19 de septiembre de 2006 (par. 174, punto 9); CIDH, Caso Almonacid Arellano vs. Chile, de 26 de septiembre de 2006 (par. 171 punto 7); CIDH, Caso Atala Riffo y Niñas vs. Chile, de 24 de febrero de 2012 (par. 314, punto 6).

${ }_{29} \mathrm{CIDH}$, Caso Olmedo Bustos y otros vs. Chile, de 5 de febrero de 2001 (par. 103, punto 4).

${ }^{30}$ CIDH, Caso Palamara Iribarne vs. Chile, de 22 de noviembre de 2005 (par. 269, puntos 13-15).

${ }^{31} \mathrm{CIDH}$, Caso Claude Reyes y otros vs. Chile, de 19 de septiembre de 2006 (par. 174, puntos 7-8).

32 CIDH, Caso Almonacid Arellano vs. Chile, de 26 de septiembre de 2006 (par. 171 puntos 5-6).

${ }_{33}$ CIDH, Caso Palamara Iribarne vs. Chile, de 22 de noviembre de 2005 (par. 269, punto 12).

${ }_{34} \mathrm{CIDH}$, Caso Olmedo Bustos y otros vs. Chile, de 5 de febrero de 2001 (par. 103 punto 4).

35 CIDH, Caso Palamara Iribarne vs. Chile, de 22 de noviembre de 2005 (par. 269, punto 9).

${ }^{36}$ CIDH, Caso Claude Reyes y otros vs. Chile, de 19 de septiembre de 2006 (par. 174, punto 5). 
un plazo razonable, en materia de acceso a la información pública a los órganos, autoridades o agentes públicos encargados de atender las solicitudes de acceso a la información bajo control del Estado ${ }^{37}$ y seguir implementando programas y cursos permanentes de educación y capacitación dirigidos a funcionarios públicos y particularmente a funcionarios judiciales de los distintos escalafones del poder judicial en materia de discriminación por orientación sexual ${ }^{38}$; k) brindar atención médica y psicológica o psiquiátrica gratuita y de forma inmediata, adecuada y efectiva, a través de sus instituciones públicas de salud a las víctimas que así lo soliciten $^{39}$, y k) realizar un acto público de reconocimiento de responsabilidad internacional. ${ }^{40}$

\section{Cumplimiento y ejecución de las Sentencias de la CORTE POR EL ESTADO DE CHILE}

El artículo 68.1 de la CADH estipula que "Los Estados Partes en la Convención se comprometen a cumplir la decisión de la Corte en todo caso en que sean partes", compromiso que los Estados debe observar de buena fe, de acuerdo al principio básico de responsabilidad internacional de que lo pactado obliga "pacta sunt servanda", estándoles vedado invocar razones de orden interno para excusarse de cumplir sus obligaciones convencionales internacionales, conforme lo dispone el artículo 27 de la "Convención de Viena sobre Derecho de los Tratados".

"Los Estados Partes en la Convención deben garantizar el cumplimiento de las disposiciones convencionales y sus efectos propios (effet utile) en el plano de sus respectivos derechos internos. Este principio se aplica no sólo en relación con las normas sustantivas de los tratados de derechos humanos (es decir, las que contienen disposiciones sobre los derechos protegidos), sino también en relación con las normas procesales, como las que se refieren al cumplimiento de las decisiones del Tribunal. Estas obligaciones deben ser interpretadas y aplicadas de manera que la garantía protegida sea verdaderamente práctica y eficaz, teniendo presente la naturaleza especial de los tratados de derechos humanos". ${ }^{1}$

37 CIDH, Caso Claude Reyes y otros vs. Chile, de 19 de septiembre de 2006 (par. 174, punto 8).

$38 \mathrm{CIDH}$, Caso Atala Riffo y Niñas vs. Chile, de 24 de febrero de 2012 (par. 314, punto 5).

$39 \mathrm{CIDH}$, Caso Atala Riffo y Niñas vs. Chile, de 24 de febrero de 2012 (par. 314, punto 2).

$40 \mathrm{CIDH}$, Caso Atala Riffo y Niñas vs. Chile, de 24 de febrero de 2012 (par. 314, punto 3).

${ }^{41} \mathrm{CIDH}$, Caso Olmedo Bustos y otros vs. Chile, resolución de cumplimiento de sentencia, de 28 de noviembre de 2002; CIDH, Caso Palamara Iribarne vs. Chile, resolución de cumplimiento de sentencia, de 30 de 
La propia CIDH se ha reservado en sus sentencias la facultad de supervisar el cumplimiento de sus fallos (atribución inherente a sus funciones jurisdiccionales) imponiéndole al Estado, en algunas de éstas, la obligación de informar sobre las medidas adoptadas para darle cumplimiento. ${ }^{42}$

El Estado de Chile ha cumplido íntegramente con aquellas medidas de reparación consistentes en pago de indemnizaciones de perjuicios, reintegro de gastos y costas del proceso, y publicación de las sentencias. Sin embargo, son las otras medidas, en especial las relativas a la adecuación del ordenamiento jurídico interno a los estándares internacionales y las consistentes en el deber de investigar y sancionar las violaciones a los derechos humanos, las que han presentado mayores dificultades en su ejecución, como veremos a continuación.

\section{Olmedo Bustos y otros vs. Chile}

La sentencia dictada en el presente caso se encuentra íntegramente cumplida por lo que la Corte ha dado por terminado el caso y ha ordenado archivar el expediente. ${ }^{43}$

Resulta interesante el análisis de aquella parte de la sentencia que ordenó al Estado modificar su ordenamiento jurídico interno, en un plazo razonable, con el fin de suprimir la censura previa para permitir la exhibición de la película "La Última Tentación de Cristo", ya que ello implicaba una reforma constitucional.

Con anterioridad al fallo de la CIDH, el Estado había iniciado ya un proceso de modificación a su legislación a través de un proyecto de reforma constitucional que perseguía consagrar el derecho a la libre creación artística y eliminar la censura cinematográfica, sustituyéndola por un sistema de calificación, ajustándose de esta forma a los estándares internacionales. La urgencia de esta reforma constitucional se hizo patente cuando la Corte de Apelaciones de Santiago acogió

noviembre de 2007; CIDH, Caso Claude Reyes y otros vs. Chile, resolución de cumplimiento de sentencia, de 2 de mayo de 2008; CIDH, Caso Almonacid Arellano vs. Chile, resolución de cumplimiento de sentencia, de 18 de noviembre de 2010.

${ }^{42} \mathrm{CIDH}$, Caso Olmedo Bustos y otros vs. Chile, de 5 de febrero de 2001 (par. 103, punto 6); CIDH, Caso Palamara Iribarne vs. Chile, de 22 de noviembre de 2005 (par. 269, punto 19); CIDH, Caso Claude Reyes y otros vs. Chile, de 19 de septiembre de 2006 (par. 174, punto 10); CIDH, Caso Almonacid Arellano vs. Chile, de 26 de septiembre de 2006 (par. 171, punto 9); CIDH, Caso Atala Riffo y Niñas us. Chile, de 24 de febrero de 2012 (par. 314, punto 8).

${ }^{43} \mathrm{CIDH}$, Caso Olmedo Bustos y otros vs. Chile, resolución de cumplimiento de sentencia, de 28 de noviembre de 2003. 
un recurso de protección, prohibiendo la exhibición de la película en cuestión, evidenciando de esta forma la posición de los tribunales de justicia nacionales en orden a dar aplicación preferente al derecho al honor por sobre el derecho a la libertad de expresión.

Este criterio de los tribunales nacionales no era compartido por el Gobierno de la época. Ello motivó un proyecto de reforma constitucional que fue iniciado por mensaje del Presidente de la República (Sr. Eduardo Frei Ruiz-Tagle), el que fue presentado a la Cámara de Diputados el 16 de abril de 1997.

Durante la discusión general del proyecto de reforma constitucional, el Ministro Secretario General de la Presidencia de la época, Sr. José Miguel Insulza, señaló que: "este proyecto de ley no fue apurado - como creen algunos- sólo porque existe consenso entre los candidatos presidenciales respecto de esta materia, sino por una razón muy práctica. Hoy se discute en la Comisión Interamericana de Derechos Humanos una condena a Chile por haber prohibido la exhibición de la pelicula 'La última tentación de Cristo'. Por ese motivo, desde hace tiempo se viene planteando la necesidad de abolir la censura cinematográfica, como una forma de demostrar que en este pais efectivamente existe plena libertad de expresión. Al Ejecutivo le pareció que una buena señal en tal sentido era que, al menos, se aprobara en primer trámite constitucional este proyecto de reforma constitucional, antes de que se emita un fallo que sería-quiero advertirlo aqui-condenatorio para nuestro pais". 44

Se evidencia de esta forma la preocupación existente en el Gobierno por adecuar la normativa interna a los compromisos internacionales y por las consecuencias que un fallo desfavorable de la Corte podría implicar para el Estado en materia de responsabilidad internacional. Esta circunstancia, unida a la proximidad de las elecciones presidenciales en el país permitió presionar al órgano constituyente y lograr un consenso para la adopción de esta reforma.

En la discusión del proyecto en el Senado, el senador Chadwick señaló que esta reforma "no responde ni obedece a ninguna voluntad externa. No estamos obligados a incorporarla porque existan tratados internacionales sobre la materia, pues ninguno de éstos se halla por sobre la Constitución; ni tampoco porque existan sentencias o porque tribunales internacionales se hayan pronunciado con respecto al asunto. La conocemos por la voluntad soberana que tiene este Parlamento de ejercer su facultad constituyente, sin necesidad de estar subordinado a ninguna legislación internacional

${ }_{44}$ Cámara de Diputados, Discusión en Sala, Legislatura 341, Sesión 17, de 17 de noviembre de 1999 , (fecha de consulta: 2 de noviembre de 2012). Disponible en http://www.leychile.cl/Navegar?idNorma=24 2302\&eh=True. 
ni a ninguna resolución de tribunal internacional. De hecho, esta reforma se está tramitando aqui desde hace bastante tiempo". ${ }^{45}$

Distinta fue la opinión del senador Viera Gallo, quien señaló que: "no podríamos proceder de otra manera, porque Chile voluntariamente se sometió a su jurisdicción. Es decir, firmó un tratado no sólo referente a la creación de dicho tribunal, sino que se sometió a su jurisdicción. El Estado chileno fue condenado por la Corte Interamericana de Derechos Humanos, y nosotros estamos dando cumplimiento a dicho fallo mediante un acto positivo, que es eliminar la censura". ${ }^{46}$

Lo anterior nos va demostrando la diversa postura que tienen las distintas bancadas políticas respecto al carácter vinculante y a la jerarquía del Derecho Internacional de los Derechos Humanos, lo que permite entender la dificultad que existe para la adopción de las medidas de reparación que nos impone la $\mathrm{CIDH}$.

La Ley de Reforma Constitucional No 19.742, que eliminó la censura previa, reemplazándola por un sistema de calificación cinematográfica, fue aprobada en junio de 2001 y publicada el 25 de agosto de ese año. El 9 de enero de 2003 la película fue recalificada por el nuevo Consejo de Calificación como película para mayores de 18 años, permitiéndose de esta forma su exhibición y dándose, de esta forma, cumplimiento íntegramente a la sentencia de la CIDH.

\section{Claude Reyes y otros vs. Chile}

La sentencia de la CIDH, al igual que en el caso anterior, se encuentra íntegramente cumplida.

Las medidas de reparación impuestas por la CIDH consistieron, entre otras, en: a) el deber de entregar, a través de la entidad correspondiente, la información solicitada, o bien, adoptar una decisión fundamentada al respecto; b) el deber de adoptar, en un plazo razonable, las medidas necesarias para garantizar el derecho de acceso a la información bajo control del Estado, y c) el deber de capacitar a los órganos y agentes públicos encargados de atender las solicitudes de acceso a la información bajo control del Estado sobre la normativa que rige este derecho, que incorpore los parámetros convencionales que deben respetarse en materia de restricciones al acceso a dicha información.

45 Senado. Legislatura 343, Sesión 40, de 2 de mayo de 2001, (fecha de consulta: 2 de noviembre de 2012). Disponible en http://www.leychile.cl/Navegar?idNorma=242302\&eh=True.

46 Senado. Legislatura 343, Sesión 40, de 2 de mayo de 2001, (fecha de consulta: 2 de noviembre de 2012). Disponible en http://www.leychile.cl/Navegar?idNorma=242302\&eh=True. 
En relación con la obligación de informar o fundar la negativa de entregar información, el Estado cumplió, remitiendo a la Corte una nota del Comité de Inversiones Extranjeras donde se explicaba que parte de la información requerida no había podido ser entregada, pues ella no obraba en poder del Comité y se trataba de materias respecto de las cuales este órgano carecía de facultades legales para requerirla a los inversionistas, circunstancias que, sin embargo, no habían sido explicadas oportunamente a los requirentes.

Respecto del deber de adoptar las medidas necesarias para garantizar el derecho de acceso a la información bajo control del Estado, debemos mencionar que con anterioridad al fallo de la CIDH se había dado inicio ya a un proceso de adecuación del ordenamiento jurídico interno, con el objeto de incorporar principios y normas de probidad y transparencia en el ejercicio de la función pública, a través de la Ley No 19.653 ("Ley de Probidad" de 14 diciembre de 1999). Sin embargo, a juicio de la Comisión IDH y de los representantes, tales reformas resultaban insuficientes según los estándares internacionales en materia de derecho de acceso a la información, pues no se regulaban las limitaciones que el ejercicio de este derecho puede permitir, las que sólo pueden tener lugar en los casos que señala la CADH. Además, esta ley dejaba abierta la posibilidad para que por vía reglamentaria se establecieran los casos de secreto o reserva de la documentación y antecedentes que obraren en poder de la Administración del Estado, lo cual claramente constituye una grave barrera al acceso a dicha información.

En efecto, el Decreto Supremo No 26, de 28 de enero de 2001, del Ministerio Secretaría General de la Presidencia, dispuso en su artículo $9^{\circ}$ que los órganos de la administración del Estado debían clasificar los actos y documentos que generen, como secretos o reservados, en conformidad a los restrictivos criterios establecidos en su artículo $8^{\circ}$. Esto permitió que numerosas reparticiones públicas dictaran sendas resoluciones en tal sentido, restringiendo administrativamente el derecho a la información a niveles que lo hacen prácticamente inexistente. Así lo constató además la Contraloría General de la República en Dictamen No 049883 de 4 de octubre de 2004, donde señala que en tales resoluciones "no se advierte el fundamento preciso para declarar secretos o reservados determinados documentos" ${ }^{47}$

47 Dictamen No 049883 de 4 de octubre de 2004, (fecha de consulta: 2 de noviembre de 2012). Disponible en http://www.leychile.cl/Consulta/portada_hl?tipo_norma=XX1\&nro_ley=20285\&anio=2012. 
Esta situación fue considerada durante la tramitación de la Ley de Reforma Constitucional No 20.050 de 26 de agosto de 2005, que modifica el artículo $8^{\circ}$ de la Constitución, incorporando el principio de publicidad de los actos de Gobierno y estableciendo que sólo una ley de quórum calificado podría establecer su secreto o reserva. ${ }^{48}$

Siguiendo con la línea de fortalecimiento del derecho de acceso a la información que obra en poder del Estado, el 4 de enero de 2005 (un año y medio antes de la sentencia de la CIDH), los senadores Jaime Gazmuri y Hernán Larraín F. presentaron un proyecto de ley sobre acceso a la información pública, con el objeto de asegurar una mayor transparencia en el ejercicio de las funciones públicas y lograr una mayor participación ciudadana en los asuntos públicos, todo lo cual contribuye a fortalecer el régimen democrático de gobierno. Este proyecto dio lugar a la aprobación y promulgación de la Ley No 20.285 sobre "Transparencia de la Función Pública y Acceso a la Información de la Administración del Estado", de 20 de agosto de 2008.

En la audiencia de supervisión de cumplimiento ante la CIDH, el Estado de Chile destacó: "la extraordinaria contribución que significó para el acceso de información pública, para el fortalecimiento de la libertad de expresión" la Sentencia dictada por la Corte en el presente caso; señaló que la sentencia fue "objeto también de un reconocimiento de parte de muchos de los análisis y de los artículos que dio lugar la promulgación de esta ley de transparencia y probidad" y refirió opiniones en el sentido de que el nuevo texto de la ley es "más completo en gran medida debido a la influencia de la condena del Estado de Chile que hiciera la Corte Interamericana". ${ }^{49}$

Por último, respecto de la obligación de capacitar a los órganos, autoridades y agentes públicos encargados de atender las solicitudes de acceso a información bajo el control del Estado, se da también por cumplida la sentencia en virtud de la realización de una serie de seminarios para los órganos de gobierno, por la edición de un Manual para la Transparencia y Probidad de la Administración del Estado, y por la aprobación, en la ley de presupuesto del año 2008, de recursos para iniciar un Plan Quinquenal de Capacitación en Probidad y Transparencia, entre otras.

48 Cámara de Diputados, Legislatura 352, Sesión 79, de 18 de mayo de 2005, (fecha de consulta: 2 de noviembre de 2012). Disponible en http://www.leychile.cl/Navegar?idNorma=242302\&eh=True.

${ }^{49} \mathrm{CIDH}$, Caso Claude Reyes y otros vs. Chile, resolución de cumplimiento de sentencia, de 24 de noviembre de 2008 (par. 10). 


\section{Palamara Iribarne vs. Chile}

Dentro de las medidas de reparación impuestas en este caso y cuyo estado de cumplimiento nos interesa analizar aquí, encontramos: a) dejar sin efecto, en el plazo de seis meses, en todos sus extremos, las sentencias condenatorias pronunciadas contra el señor Humberto Palamara I.; b) adoptar todas las medidas necesarias para derogar y modificar, dentro de un plazo razonable, las normas internas que sean incompatibles con los estándares internacionales en materia de libertad de pensamiento y de expresión; c) adecuar, en un plazo razonable, el ordenamiento jurídico interno a los estándares internacionales sobre jurisdicción penal militar, de forma tal que en caso de que considere necesaria la existencia de una jurisdicción penal militar, ésta debe limitarse solamente al conocimiento de delitos de función cometidos por militares en servicio activo, limitando la competencia material y personal de los tribunales militares de tal forma que en ninguna circunstancia un civil se vea sometido a dicha jurisdicción, y d) garantizar el debido proceso en la jurisdicción penal militar y la protección judicial respecto de las actuaciones de las autoridades militares.

Para dar cumplimiento a la obligación de dejar sin efecto las sentencias condenatorias fue necesario idear un mecanismo que permitiera la supresión de los antecedentes penales en el Registro General de Condenas, a través de la correspondiente resolución administrativa, puesto que las penas se encontraban cumplidas a la fecha de la dictación de la sentencia. Se acreditó el cumplimiento de esta medida a través de un certificado de fecha 26 de octubre de 2007, emitido por el Director Nacional de Registro Civil e Identificación, en el que consta que el señor Humberto Palamara Iribarne aparece sin antecedentes en el Registro General de Condenas.

Sin embargo, las medidas de reparación consistentes en una adecuación del ordenamiento jurídico interno a los estándares internacionales han resultado más difíciles de cumplir. Estas se traducen en la derogación del delito de desacato y delimitación del delito de amenazas y la reforma a la jurisdicción penal militar.

a. Deber de adoptar todas las medidas necesarias para derogar y modificar, dentro de un plazo razonable, las normas internas que sean incompatibles con los estándares internacionales en materia de libertad de pensamiento y de expresión.

La CIDH declaró que el delito de desacato no se ajustaba a la Convención pues imponía una restricción desproporcionada al ejercicio de la libertad de ex- 
presión, por cuanto inhibía a los particulares de formular expresiones contra la autoridad por temor a la sanción que traía aparejada esta figura penal. Citando un informe de la OEA ha dicho que: las "leyes de desacato proporcionan un mayor nivel de protección a los funcionarios públicos que a los ciudadanos privados, en directa contravención con el principio fundamental de un sistema democrático, que sujeta al gobierno a controles, como el escrutinio público, para impedir y controlar el abuso de sus poderes coercitivos" 50

Asimismo, la Corte ha señalado anteriormente que el Derecho Penal es el medio más restrictivo y severo para establecer responsabilidades respecto de una conducta ilicita". 51

En relación con el cumplimiento de esta parte de la sentencia debemos señalar que ya durante la tramitación de la causa ante la CIDH, el Ejecutivo había dado inicio a un proceso de reforma legislativa en materia de delito de desacato, señalando en el Mensaje No 212-347 del proyecto respectivo, que "la figura del desacato [...] no parece constituir una restricción legitima al ejercicio de las libertades de pensamiento, opinión e información", así como que "la persistencia de estas normas [...] ha derivado en un privilegio sin fundamento [...] en favor de ciert[o]s [funcionarios públicos..., lo cual] impide, mediante el temor a la pena que se podría imponer [,...] que se desarrolle plenamente el libre debate [...e inhibe el] control ciudadano [sobre] quienes desarrollan tareas de decisión y conducción politica".52

El 31 de agosto de 2005, tres meses antes de la dictación de esta sentencia, se publicó la Ley No 20.048 que modificó el Código Penal y el de Justicia Militar en materia de desacato (esta ley derogó el delito de desacato del Código Penal y modificó el artículo 264 del mismo, sin embargo, no derogó la figura de desacato contemplada en el artículo 284 del Código de Justicia Militar).

Si bien, la Corte valoró en su momento que el Estado haya derogado el delito de desacato en el Código Penal, hizo presente, sin embargo, que el delito de amenazas tipificado en el artículo $264^{53}$ del mismo Código contempla una

\footnotetext{
50 Informe sobre la compatibilidad entre las leyes de desacato y la CADH. OEA/Ser.L/V/II.88, doc. 9 rev., 17 de febrero de 1995. Citado por Meier (2011), p. 337.

51 CIDH, Caso Palamara Iribarne vs. Chile, de 22 de noviembre de 2005 (par. 85).

52 CIDH, Caso Palamara Iribarne vs. Chile, de 22 de noviembre de 2005 (par. 86).

53 Código Penal, Art. 264, inc. 10: "El que amenace durante las sesiones de los cuerpos colegisladores o en las audiencias de los tribunales de justicia a algún diputado o senador o a un miembro de dichos tribunales, o a un senador o diputado por las opiniones manifestadas en el Congreso, o a un miembro de un tribunal de justicia por los fallos que hubiere pronunciado o a los ministros de Estado u otra autoridad en el ejercicio de sus cargos, será castigado con reclusión menor en cualquiera de sus grados".
} 
descripción muy ambigua de la figura delictiva, lo que puede llevar a que por medio de una interpretación amplia del mismo, las conductas anteriormente consideradas como desacato sean penalizadas indebidamente a través del tipo penal de amenazas. Observó con preocupación finalmente, que el Código de Justicia Militar continúa tipificando el delito de desacato, contemplándose de esta manera una protección mayor a las instituciones militares y sus miembros de la que no gozan las instituciones civiles en una sociedad democrática. ${ }^{54}$

Por lo anterior, la Corte, en ejercicio de la facultad de supervisión de cumplimiento de sentencia, requirió al Estado para que brinde información sobre las medidas adoptadas para derogar el delito de desacato del Código de Justicia Militar y delimitar claramente la figura típica de amenazas contemplada en el artículo 264 del Código Penal. ${ }^{55}$

Respecto del delito de desacato contemplado en el Código de Justicia Militar, el Estado informó a la Corte, en julio de 2011, que existía pleno acuerdo en derogar dicha figura, pues "se trata de un delito que no reviste caracteres propiamente castrenses y restringe severamente el discurso público y el rol que una opinión pública informada ejerce en el seno de una sociedad democrática". En cuanto a la forma de derogación señaló que 'el Ejecutivo ha [bia] optado por la directa derogación [,] y no una mera reforma o modificación', mediante el proyecto de ley llamado 'Jurisdicción y Competencia de los Tribunales Militares y Procedimiento Ante Ellos' que habia ingresado a la Cámara de Diputados el 27 de octubre de 2009. Posteriormente, Chile indicó que el 9 de septiembre de 2010 el Presidente de la República retiró el mencionado proyecto de ley de su tramitación en el Congreso Nacional, e ingresó a la Cámara de Diputados un nuevo proyecto de ley, incluido en el boletín legislativo $N^{o}$ 7203-02, relativo a la reforma de la justicia militar, que 'al igual que el anterior, contempla[ría] la derogación del delito de desacato, atendiendo a que su existencia no se adecua a los estándares internacionales en la materia'”. 56

Pero, respecto del delito de amenazas, el Estado defendió la subsistencia de éste pues persigue proteger la función pública y evitar que mediante la amenaza las autoridades actúen de manera coaccionada, aunque reconoció que es una figura delictiva que adolece de ciertos defectos técnicos, porque no aparece tan claro

${ }^{4}$ CIDH, Caso Palamara Iribarne vs. Chile, de 22 de noviembre de 2005 (par. 92-93).

$55 \mathrm{CIDH}$, Caso Palamara Iribarne vs. Chile, supervisión de cumplimiento de sentencia, de 30 de noviembre de 2007 y de 21 de septiembre de 2009.

$56 \mathrm{CIDH}$, Caso Palamara Iribarne vs. Chile, supervisión de cumplimiento de sentencia, de 1 de julio de 2011 (par. 6). 
cuál es el bien jurídico protegido. Sostuvo además que este delito no se relaciona con la libertad de expresión, pues las amenazas no pueden considerarse como un legítimo ejercicio de ese derecho. ${ }^{57}$

Agregó, finalmente, que el nuevo proyecto de ley de reforma de la justicia militar "mantiene las figuras calificadas del delito de amenazas respecto de las personas que integran las Fuerzas Armadas y de Orden [...] debido al respeto que merecen sus funciones e investiduras. Por otro lado, en la propuesta de reforma del artículo 284 del Código de Justicia Militar, la descripción del tipo penal se ha[ría] acotada y las circunstancias de comisión muy precisas, de manera de evitar una posible interpretación [...] que pudiere llevar a que conductas consideradas como desacato sean penalizadas indebidamente a través del tipo penal de amenazas". 58

La Corte reconoce que si bien se han presentado propuestas legislativas para derogar el delito de desacato y se debatió la reforma del delito de amenazas, ambas figuras siguen vigentes, sin que el Estado haya informado avances sustanciales en relación con el cumplimiento de esta medida de reparación, por lo que resolvió reiterar al Estado que debe adoptar todos los mecanismos necesarios para el cumplimiento de esta medida que se encuentra aún pendiente. ${ }^{59}$

b. Deber de adecuar el ordenamiento jurídico interno a los estándares internacionales sobre jurisdicción penal militar y establecer, a través de su legislación, límites a la competencia material y personal de los tribunales militares, y el deber de garantizar el debido proceso en la jurisdicción penal militar y la protección judicial respecto de las actuaciones de las autoridades militares.

La Corte ha señalado que:

"En un Estado democrático de derecho la jurisdicción penal militar ha de tener un alcance restrictivo y excepcional y estar encaminada a la protección de intereses jurídicos especiales, vinculados con las funciones que la ley asigna a las fuerzas militares. Por ello, sólo se debe juzgar a militares por la comisión de delitos o faltas que por su propia naturaleza atenten contra bienes juridicos propios del orden militar". ${ }^{60}$

$57 \mathrm{CIDH}$, Caso Palamara Iribarne vs. Chile, supervisión de cumplimiento de sentencia, de 1 de julio de 2011 (par. 7).

$58 \mathrm{CIDH}$, Caso Palamara Iribarne vs. Chile, supervisión de cumplimiento de sentencia, de 1 de julio de 2011 (par. 7).

$59 \mathrm{CIDH}$, Caso Palamara Iribarne vs. Chile, supervisión de cumplimiento de sentencia, de 1 de julio de 2011.

${ }^{60}$ CIDH, Caso Palamara Iribarne vs. Chile, de 22 de noviembre de 2005 (par. 124); CIDH, Caso Almonacid Arellano vs. Chile, de 26 de septiembre de 2006 (par. 131); CIDH, Caso de la "Masacre de Mapiripán” vs. Co- 
La Corte ha cuestionado la jurisdicción penal militar chilena por la amplitud de su competencia y por no respetar los principios de imparcialidad e independencia de los tribunales.

En relación con la Justicia Militar en Chile, se han presentado más de tres proyectos de reforma, planteándose por algunos la necesidad de suprimirla absolutamente o a lo menos en tiempos de paz, dejando entregado el conocimiento de los delitos que hoy son de competencia de la jurisdicción castrense a la justicia ordinaria. Las razones que se dan para ello son, entre otras, que no se justifica la subsistencia de este tipo especial de competencia en un estado democrático de derecho, debiendo reforzarse la jurisdicción disciplinaria y mantener lo penal en la justicia ordinaria. ${ }^{61}$ Sin embargo, hay quienes defienden la subsistencia de la Justicia Militar, aun en tiempos de paz, por tratarse de temas muy técnicos que requieren de una judicatura especializada. ${ }^{62}$

En lo que si hubo acuerdo generalizado fue en la necesidad de restringir la competencia de la justicia militar para dejar a los civiles fuera de la jurisdicción castrense.

Durante el Gobierno de la Concertación (específicamente de la Presidenta Michelle Bachelet Jeria), se impulsaron diversas reformas, por iniciativa del Ejecutivo. La estrategia legislativa desarrollada separó las materias a tratar en tres proyectos de ley: 1) Proyecto de ley que modifica el Código de Justicia Militar alterando la competencia de los Tribunales Militares y suprimiendo la pena de muerte; ${ }^{63} 2$ ) Proyecto de ley sobre delitos militares y sus penas, de octubre de $2009,{ }^{64}$ que pretendía crear un nuevo catálogo de delitos militares de carácter estricto, cometidos sólo por militares y que afectaren bienes jurídicos militares; 3) Proyecto de ley sobre jurisdicción y competencia de los tribunales militares y

lombia, de 15 de septiembre de 2005 (par. 202); CIDH, Caso Lori Berenson Mejía vs. Perú, de 25 de noviembre de 2004 (par. 142), y CIDH, Caso 19 Comerciantes vs. Colombia, de 5 de julio de 2004 (par. 165).

${ }^{61}$ Oficio de la Corte Suprema a la Cámara de Diputados No 276, de 7 de diciembre de 2009.

62 Senador Prokurica, en su intervención en la discusión general del proyecto ante la Comisión de Constitución, Legislación, Justicia y Reglamento en relación con el proyecto de ley que buscaba modificar el Código de Justicia Militar, alterando la competencia de los Tribunales Militares y suprimir la pena de muerte. Boletín No 5.159-07, (fecha de consulta: 2 de noviembre de 2012). Disponible en http://www. camara.cl/pley/pley_detalle.aspx?prmID=5542\&prmBL=5159-07.

63 Boletín No 5.159-07, (fecha de consulta: 2 de noviembre de 2012). Disponible en http://www.camara. cl/pley/pley_detalle.aspx?prmID=5542\&prmBL=5159-07.

64 Boletín No 6.734-02, (fecha de consulta: 2 de noviembre de 2012). Disponible en http://www.camara. cl/pley/pley_detalle.aspx?prmID=7128\&prmBL=6734-02. 
procedimientos ante ellos. ${ }^{65}$ Este proyecto buscaba además derogar el delito de desacato del Código de Justicia Militar y adoptar para la jurisdicción castrense el modelo procesal penal de la justicia ordinaria, de corte acusatorio, en vez del modelo inquisitivo.

Hago presente que, tanto en los Mensajes del Ejecutivo que acompañaban a estos proyectos como en la tramitación de los mismos, se dejó constancia que estas iniciativas legislativas buscaban dar solución a las objeciones formuladas por la CIDH en materia de Justicia Militar. Sin embargo, ninguna de estas iniciativas llegó a convertirse en ley; las dos primeras por el archivo de dichos proyectos y la tercera por el retiro del proyecto que efectuara el Presidente Sebastián Piñera E., en septiembre de 2010.

El 9 de septiembre de 2010, el Presidente de la República (Sr. Sebastián Piñera E.) presentó a la Cámara de Diputados, con suma urgencia presidencial, un nuevo proyecto de ley ${ }^{66}$ que pretendía modificar el sistema de justicia militar, delimitando en forma precisa su jurisdicción y competencia para excluir totalmente de su ámbito de acción y aplicación, a los civiles. Dicho proyecto se convirtió en la Ley No 20.477 de diciembre de 2010, que "Modifica la competencia de los Tribunales Militares", estableciendo que ni los civiles ni los menores de edad estarán sujetos a la competencia de los tribunales militares, la cual corresponde a los tribunales ordinarios. Y, en caso de coautoría y coparticipación de civiles y militares en la comisión de delitos sujetos a la justicia militar, serán competentes, respecto de los civiles, la Justicia Ordinaria y, respecto de los militares, los Tribunales Militares. Por último, el art. $6^{\circ}$ de esta ley delimita quiénes serán considerados militares.

El Ministro de Justicia de la época, Sr. Felipe Bulnes Serrano, siguiendo el criterio de la Administración anterior, manifestó la conveniencia de abordar la reforma a la Justicia Militar por etapas, por la ventaja que esto presenta para la adopción de acuerdos, pues ya se había logrado un consenso en cuanto a excluir a los civiles de la justicia castrense, pero aún está pendiente la definición de los delitos militares, que requerirá de un mayor debate y discusión, así como la reforma a la estructura orgánica y los procedimientos ante la Justicia Militar para ajustarla a los principios que inspiran al sistema procesal penal.

${ }^{65}$ Boletín No 6.739-02, (fecha de consulta: 2 de noviembre de 2012). Disponible en http://www.camara. cl/pley/pley_detalle.aspx?prmID=7134\&prmBL=6739-02.

${ }^{66}$ Boletín No 7.203-02, (fecha de consulta: 2 de noviembre de 2012). Disponible en http://www.camara. cl/pley/pley_detalle.aspx?prmID=7602\&prmBL=7203-02. 
Originalmente el proyecto no sólo buscaba excluir de la jurisdicción militar los delitos cometidos por civiles, sino también derogar el delito de desacato del Código de Justicia Militar y establecer un régimen más estricto de sanciones tratándose de delitos contra los miembros de las policías.

Pero hubo un factor de hecho que fue determinante para que finalmente sólo se discutiera lo relativo a la competencia de los tribunales castrenses, comprometiéndose el Ministro de Justicia, Felipe Bulnes, a tratar las otras materias en un proyecto futuro. Estos hechos se refieren a la huelga de hambre de varios comuneros mapuches por la aplicación de la Ley Antiterrorista, y por los dobles enjuiciamientos a los que se veían sometidos (ante la Justicia Ordinaria y la Justicia Militar). El acuerdo de reformar la justicia militar, excluyendo de su competencia a los civiles, permitió deponer la huelga de hambre de los comuneros mapuches.

Lo destacable en la tramitación de este proyecto de ley es que a diferencia de los que se sostenía, tanto en los mensajes presidenciales ${ }^{67}$ de los proyectos impulsados por el gobierno anterior, como en el debate de los mismos, en torno a que estas reformas obedecían a la necesidad de ajustar el ordenamiento jurídico a los estándares internacionales, el nuevo Gobierno expresamente indicó que este proyecto no responde a ningún compromiso internacional y que su premura obedece fundamentalmente a salvar la situación de huelga de hambre de los mapuches para excluirlos de la Justicia Militar. ${ }^{68}$ Así lo señaló también expresamente el diputado señor Jorge Ulloa en la discusión del proyecto dentro de la Cámara de Diputados ${ }^{69}$ destacando el hecho de que este proyecto fue presentado para resolver el conflicto de la huelga de hambre de los comuneros mapuches.

\footnotetext{
${ }^{67}$ Véase Mensaje de la Presidenta de la República de 22 de julio de 2007 No 369/355 sobre proyecto de ley que modifica el Código de Justicia Militar, alterando la competencia de los Tribunales Militares y suprimiendo la pena de muerte; la opinión del Subsecretario de Guerra de la época, Sr. Gonzalo García y del profesor Jaime Couso que constan del Informe de la Comisión Constitución, Legislación, Justicia y Reglamento, Boletín No 5.159-07; Mensaje de la Presidenta de la República, No 1261-357, de 29 de septiembre de 2009, del Proyecto de Ley sobre Jurisdicción y Competencia de los Tribunales Militares y Procedimientos ante ellos, (fecha de consulta: 2 de noviembre de 2012). Disponible en http://www. camara.cl/pley/pley_detalle.aspx?prmID=5542\&prmBL=5159-07.

${ }^{68}$ Informe de Comisión de Constitución, Legislación y Justicia y Defensa Nacional Unidas. Cámara de Diputados, Legislatura 358, Cuenta en Sesión 82, de 29 de septiembre de 2012.

69 Cámara de Diputados, Legislatura 358, Sesión 82, de 30 de septiembre de 2010, (fecha de consulta: 2 de noviembre de 2012). Disponible en http://www.leychile.cl/Navegar?idNorma=1021613.
} 
Fue el diputado Hugo Gutiérrez quien recordó en la Cámara ${ }^{70}$ que la reforma al Código de Justicia Militar se funda en las sentencias de la CIDH, en los casos Almonacid Arellano y Palamara Iribarne. Cita textualmente pasajes del fallo, concluyendo que, de acuerdo a lo dicho por la Corte, ningún civil debe ser arrastrado a la justicia militar y, por lo tanto, lo que se está haciendo es adecuar la legislación a los estándares internacionales. Critica, asimismo, al Gobierno de la Concertación por no haber podido reformar la Justicia Militar durante los años en que fueron gobierno y felicita al entonces Ministro de Justicia, señor Felipe Bulnes S., por su capacidad de diálogo para lograr un acuerdo en estas materias, adecuándolas a los estándares internacionales.

Pero no podemos dejar pasar la opinión del diputado Cristián Monckeberg, que nos parece errada, al señalar que: "a la Cámara no le corresponde comentar los fallos judiciales. Eso será materia de la academia y de los abogados. Aquí estamos en una Cámara Politica donde la discusión es política". ${ }^{71}$

Sin embargo, creemos que al citar el fallo en el seno de la discusión parlamentaria no se pretendía hacer un análisis jurídico del mismo, sino tenerlo presente para legislar de acuerdo a los criterios que la Corte le ha señalado al Estado como parámetros para conformar su legislación a la CADH. Y esa sentencia sí debe ser considerada por el órgano legislativo, ya que obliga al Estado, y a todos sus órganos, dentro de los cuales encontramos al Poder Legislativo, a quien justamente le corresponde dar cumplimiento al deber de adecuar la normativa interna a los compromisos internacionales, conforme lo señala el artículo segundo de la Convención.

El Estado es uno solo, pero en la medida en que cambian los Gobiernos de turno, cambian también las visiones hacia los compromisos internacionales adquiridos por el Estado y que determinarán, en consecuencia, su mayor o menor voluntad política para cumplirlos.

Finalmente, si bien el Estado ha hecho esfuerzos importantes para adecuar la jurisdicción militar a lo señalado por la Corte, aún quedan temas pendientes en los que no se ha podido legislar, tales como el relativo a la estructura, organización y garantías del debido proceso dentro de la justicia militar y la definición clara

70 Cámara de Diputados, Legislatura 358, Sesión 82, de 30 de septiembre de 2010, (fecha de consulta: 2 de noviembre de 2012). Disponible en http://www.leychile.cl/Navegar?idNorma=1021613.

${ }^{71}$ Cámara de Diputados, Legislatura 358, Sesión 82, de 30 de septiembre de 2010, (fecha de consulta: 2 de noviembre de 2012). Disponible en http://www.leychile.cl/Navegar?idNorma=1021613 
de los delitos militares. Así, la $\mathrm{CIDH}^{72}$ declaró este punto de la sentencia como no cumplido y solicitó al Estado que remitiera información sobre el estado de avance de la reforma integral a la justicia militar en Chile.

\section{Almonacid Arellano y otros vs. Chile}

La sentencia en este caso impuso al Estado las siguientes medidas de reparación: a) el deber de asegurar que el Decreto Ley No 2.191 (amnistía) no siga representando un obstáculo para investigar, identificar y, en su caso, sancionar a los responsables de la ejecución extrajudicial del señor Almonacid Arellano o de otras violaciones similares acontecidas en Chile; b) dejar sin efecto las resoluciones y sentencias emitidas en el orden interno que otorgaron competencia a la jurisdicción militar y permitieron concluir la investigación en aplicación de dicho decreto ley, y c) remitir el expediente a la justicia ordinaria, para que dentro de un procedimiento penal se identificara y sancionara a todos los responsables de la muerte del señor Almonacid Arellano. ${ }^{73}$

a. Deber de investigar, identificar y, en su caso, sancionar a los responsables de la ejecución extrajudicial del señor Almonacid Arellano.

En los informes de cumplimiento de sentencia remitidos por el Estado a la CIDH entre los años 2007 al 2010, se informó que se dejaron sin efecto las resoluciones y sentencias que sobreseyeron la causa por homicidio del Sr. Almonacid, en virtud de la aplicación del Decreto Ley No 2.191, remitiéndose el expediente a la Justicia Ordinaria y decretándose en octubre de 2007 la reapertura de la investigación, para lo cual se designó por la Corte de Apelaciones de Rancagua a un Ministro en Visita Extraordinaria.

Posteriormente, se trabó contienda de competencia entre dicho Ministro y el Segundo Juzgado Militar de Santiago, la que fue resuelta por la Corte Suprema de Justicia, estableciendo que no podía trabarse contienda de competencia con la justicia militar, puesto que la decisión de la Corte Interamericana "implicaba necesariamente la reapertura del proceso ante la judicatura ordinaria y la inaplicabilidad de la amnistía a los imputados". ${ }^{74}$

${ }^{72} \mathrm{CIDH}$, Caso Palamara Iribarne vs. Chile, supervisión de cumplimiento de sentencia, de 1 de julio de 2011.

73 CIDH, Caso Almonacid Arellano vs. Chile, de 26 de septiembre de 2006 (par. 145-147).

${ }^{74} \mathrm{CIDH}$, Caso Almonacid Arellano vs. Chile, supervisión de cumplimiento de sentencia, de 8 de noviembre de 2010, par. 6 a). 
El 24 de diciembre de 2008 el Ministro Instructor emitió una resolución en la cual decidió que, en cumplimiento de la sentencia de la CIDH, correspondía proseguir en sede civil con la investigación del sumario criminal (causa Rol No 40.184 del Primer Juzgado del Crimen de Rancagua), relativo al homicidio del señor Luis Almonacid, para lo cual ordenó desarchivar la causa; dejar sin efecto la resolución del Segundo Juzgado Militar de Santiago, de 28 de enero de 1997, que sobreseyó a dos presuntos autores del homicidio del señor Almonacid Arellano, así como la resolución de 25 de marzo de 1998 que confirmaba dicho sobreseimiento; y, reponer el auto de procesamiento respecto de uno de ellos, como presunto autor del delito de homicidio, pues se informó que el otro imputado había fallecido.

El 18 de agosto de 2011 se dictó sentencia definitiva de primera instancia en la que se condenó a Raúl Neveu Cortesi como autor del delito de homicidio simple, a la pena de presidio menor en su grado máximo, más las accesorias legales, concediéndosele el beneficio de libertad vigilada previsto en la Ley No 18.216. En su defensa, el procesado alegó la excepción de amnistía del Decreto Ley No 2.191, la que fue desestimada por constituir este Decreto "un acto de auto exoneración de responsabilidad criminal, incompatible con las disposiciones que establecen los Convenios de Ginebra y con lo resuelto por la sentencia dictada por la Corte Interamericana de Derechos Humanos, que ha servido de base al presente enjuiciamiento". ${ }^{75}$

Otra de las defensas alegadas por el procesado fue la excepción de prescripción, la cual fue rechazada por tratarse en la especie de un ilícito cometido "en un contexto de violaciones de derechos humanos de carácter grave, sistemático y masivo por parte de los agentes del Estado, lo que conduce a calificarlo, según la doctrina, como delito de lesa humanidad y al encontrarse vigentes a la época de la perpetración del ilícito los Convenios de Ginebra del año 1949, aprobados por el Estado por el Decreto Supremo No 725 de 1951, el ilícito de autos tiene la calidad de imprescriptible". ${ }^{76}$

Se aprecia acá como la sentencia de primera instancia observa la jurisprudencia de la CIDH y la cita expresamente para rechazar las excepciones de amnistía y

75 Informe 1a Fiscalía de Rancagua, de 29 de noviembre de 2011 http://corte.poderjudicial.cl/SITCORTEPORWEB/ (fecha de consulta: 2 de noviembre de 2012).

76 Informe 1a Fiscalía de Rancagua, de 29 de noviembre de 2011 http://corte.poderjudicial.cl/SITCORTEPORWEB/ (fecha de consulta: 2 de noviembre de 2012). 
prescripción, por ser contrarias al Derecho Internacional de los Derechos $\mathrm{Hu}-$ manos.

De la sentencia definitiva apeló el condenado y formuló observaciones la parte querellante. En el escrito de observaciones al fallo, presentado por el abogado de la familia Almonacid (Sr. Mario Márquez Maldonado) ${ }^{77}$, se cuestiona la procedencia de la prescripción gradual o incompleta (consagrada en el artículo 103 del Código Penal) como circunstancia atenuante de responsabilidad penal. Funda la objeción en el hecho de que se trata acá de un delito de lesa humanidad que, en consecuencia, es imprescriptible. Sostiene que rebajar la pena por el transcurso del tiempo importa una forma de prescripción. Esta opinión no fue compartida, sin embargo, en el informe de la Fiscalía de la Corte de Apelaciones de Rancagua. ${ }^{78}$

Por último, el informe de la Fiscal Judicial de la Corte de Apelaciones de Rancagua, doña Marcia Undurraga Jensen, se hace cargo de la excepción de cosa juzgada, que a su juicio habría deducido el querellado, pero que no fue resuelta por la sentencia de primera instancia en los términos siguientes:

"Que de acuerdo a lo expresado en el numeral 1 de éste informe, la suscrita es de opinión de considerar que la excepción de cosa juzgada ha sido renovada por la defensa del sentenciado en los términos que dispone el artículo 434 del Código de Procedimiento Penal y por ende debe emitirse pronunciamiento sobre dicha excepción. Salvo mejor parecer de SS.

Si asi se considera, esta informante es de opinión de rechazar la cosa juzgada y para ello tiene presente lo expuesto en la resolución que rola a fs. 1386 de autos. En especial las obligaciones que impone la Convención Interamericana de los Derechos Humanos a los Estados contratantes. Como es el caso de nuestro pais. Asi los estados partes del tratado tienen la obligación de hacer efectiva la protección de los derecho humanos, pero esa protección no termina con la culminación de un proceso judicial interno, ni se extingue con la cosa juzgada nacional -como lo fue la dictación del sobreseimiento definitivo de autos- sino que permite la revisión de dicho proceso por la jurisdicción interamericana, aún más la cosa juzgada nacional es un requisito de procesabilidad de la jurisdicción de la Corte Interamericana. En efecto en materia de derechos humanos, los Estados partes han excepcionado su soberanía nacional para permitir, en base al derecho internacional, que el Tribunal internacional, revise las actuaciones de los poderes públicos nacionales en la tutela de los derechos humanos. (Barrios González, Boris. Estudios constitucionales,

77 Corte de Apelaciones de Rancagua, Rol No 103-2011, de 18 de octubre de 2011.

78 Corte de Apelaciones de Rancagua, 1ª Fiscalía de Rancagua, Rol No 103-2011, de 29 de noviembre de 2011. 
noviembre 2006, vol. 4, número 002). Todo ello en la forma y dentro de los plazos que establece el artículo 46 de la Convención ya individualizada, tal como ha ocurrido en la especie". 79

El 14 de enero de 2013 la Corte de Apelaciones de Rancagua resolvió la apelación deducida confirmando la sentencia de primera instancia, haciendo especialmente presente la no procedencia de las excepciones de prescripción, amnistía y cosa juzgada.

Para reforzar la improcedencia de las excepciones de prescripción y amnistía la Corte partió de la base de que lo primero que debía definirse era cuál es la fuerza obligatoria de la sentencia expedida por la CIDH en este caso ${ }^{80}$ y que dispuso que: a) el Estado había violado la CADH al aplicar el Decreto Ley de Amnistía; b) e homicidio del señor Almonacid constituye un crimen de lesa humanidad; c) lo anterior impide aplicar, además, la institución de la prescripción, y d) el Estado debe asegurar que el referido decreto no siga representando un obstáculo para la investigación de esta causa. De lo anterior, la Corte de Apelaciones de Rancagua concluye que no hay forma de cumplir el fallo del Tribunal Internacional y, a la vez, aplicar las instituciones de amnistía y prescripción, "pues ambos ejercicios son contradictorios" ${ }^{81}$

Agrega que dicha colisión se produce también con el instituto de la cosa juzgada que emana de la resolución que sobreseyó definitivamente la causa en el crimen de Luis Almonacid, pues ella impide proseguir con la investigación respectiva y eventual juzgamiento y condena de los responsables.

El tribunal del alzada concluye que: "la cuestión propuesta la tiene que resolver la judicatura nacional a favor de la aplicación del fallo de la Corte Interamericana, por diversas razones" ${ }^{2}$, entre ellas: a) el propio Estado es el que se ha obligado a ello al ratificar la CADH y la competencia de la CIDH; b) la Convención Americana es un tratado sobre derechos humanos y se ha entendido por un sector de la doctrina que sus normas tienen rango constitucional, y aun, cuando no se entienda así, lo cierto es que los derechos humanos constituyen un límite al ejercicio de la soberanía siendo un deber para los órganos del Estado respetarlos

\footnotetext{
79 Corte de Apelaciones de Rancagua, 1a Fiscalía de Rancagua, Rol No 103-2011, de 29 de noviembre de 2011.

${ }^{80} \mathrm{CIDH}$, Caso Almonacid Arellano vs. Chile, de 26 de septiembre de 2006.

81 Corte de Apelaciones de Rancagua, Rol No 103-2011, de 14 de enero de 2013, (considerando segundo).

82 Corte de Apelaciones de Rancagua, Rol No 103-2011, de 14 de enero de 2013, (considerando quinto).
} 
y promoverlos (artículo $5^{\circ}$ de la Constitución), por lo que no pueden ser conculcados por normas de derecho interno. De esta forma, si la CIDH resolvió que el Estado violó los derechos al debido proceso y al amparo por la vía judicial, al sobreseer definitivamente en aplicación del Decreto Ley de Amnistía, es innegable que es el sobreseimiento mismo lo que constituye el acto vulnerador, y por ende enfrentado éste, y la normativa legal que le da fuerza de cosa juzgada, al artículo $5^{\circ}$ de la Constitución, por una razón que combina tanto la normativa internacional como el derecho interno, esa cosa juzgada no podría operar, sin mantener la vulneración ${ }^{83}$; c) además, se trata en la especie de una cosa juzgada "aparente o fraudulenta", doctrina elaborada por la CIDH y conocida por nuestro país; y d) cuando el Estado de Chile decidió reconocer competencia la CIDH se obligó a cumplir con el artículo 68 No 1 de la Convención. La decisión de mantener o no al Estado sometido a dicha jurisdicción es una decisión de los órganos políticos y no jurisdiccionales, por lo que el tribunal de alzada sólo debe dar cumplimiento al fallo de la Corte y a los compromisos internacionales para no comprometer el honor del Estado. "Si el sobreseimiento definitivo que en la causa criminal mediaba podia removerse o no, es algo que no decide la justicia nacional, en este caso, sino que lo decidió ya la Corte Interamericana. Nuestro fallo no puede referirse a si el sobreseimiento subsiste o no, o si la cosa juzgada se puede o no aplicar aqui, sino que se refiere a si se cumple o no un fallo obligatorio, que ya desechó esa cosa juzgada y removió ese sobreseimiento". 84 "...la decisión politica de mantener a Chile bajo la jurisdicción de ese tribunal internacional, admitiendo como obligatorios para el pais sus fallos, implicaba el riesgo cierto de tener que cumplir alguno que, precisamente, desbaratara un efecto interno de cosa juzgada, como ahora ha ocurrido. Si esto se decidió, aunque fuera por omisión, por los poderes politicos, la Judicatura no puede cargar con la responsabilidad de desvincular de facto al pais de un tratado vigente, negándose a cumplir un fallo que ni siquiera plantea un escenario nuevo o desconocido, en la trayectoria jurisprudencial de la Corte Interamericana. Que eso suponga constituir a la Corte Internacional en una suerte de tribunal de nulidad respecto de fallos nacionales, es evidente. Pero que eso sea conveniente o no, es asunto que surge como debatible desde mucho antes de la decisión internacional que ahora cumplimos; surge desde que la Corte Interamericana elabora su doctrina de la cosa juzgada aparente o fraudulenta. Pero entonces, de nuevo, son los poderes

83 Corte de Apelaciones de Rancagua, Rol No 103-2011, de 14 de enero de 2013, (considerando quinto).

${ }^{84}$ Corte de Apelaciones de Rancagua, Rol No 103-2011, de 14 de enero de 2013, (considerando séptimo). 
politicos quienes han de evaluar hasta quépunto una Corte con facultades tales afecta nuestra propia soberania y hasta qué punto estiman admisible que el pais continúe sometido a esa jurisdicción. El Poder Judicial, ajeno a esas evaluaciones y decisiones, no puede, entretanto, más que cumplir aquello a que el Estado todo sigue obligado, por un tratado vigente". ${ }^{85}$

Por último, en relación con la atenuante de la media prescripción o prescripción gradual invocada por la defensa del acusado, la Corte de Apelaciones de Rancagua resolvió que, por tratarse en la especie de un delito de lesa humanidad, éste es imprescriptible (Convención de Ginebra), por lo que la prescripción no puede operar ni como eximente ni como atenuante.

De esta forma, podríamos entender casi cumplida aquella parte de la sentencia de la CIDH que imponía al Estado el deber de investigar, identificar y, en su caso, sancionar a los responsables de la ejecución extrajudicial del señor Almonacid Arellano. Sin embargo, deberemos esperar otro tiempo para ver qué resuelve la Excelentísima Corte Suprema de Justicia respecto de los recursos de casación presentados por la partes y deducidos contra el fallo de la Corte de Apelaciones de Rancagua.

b. Asegurar que el Decreto Ley No 2.191 no siga representando un obstáculo para investigar, identificar y, en su caso, sancionar a los responsables de las graves violaciones a los derechos humanos acontecidas en Chile.

Durante el período de los gobiernos de facto en Latinoamérica se dictaron numerosas leyes de amnistía con el objeto de asegurar la impunidad de los responsables por las graves violaciones a los derechos humanos cometidos durante la época de represión contra la población civil.

La amnistía, cosa juzgada y prescripción de la acción penal se convirtieron en las instituciones propicias para dejar de investigar y, en su caso, sancionar a los responsables de tales crímenes.

La CIDH se ha pronunciado sobre la incompatibilidad de dichos institutos con el Derecho Internacional señalando que:

"Son inadmisibles las disposiciones de amnistia, las disposiciones de prescripción y el establecimiento de excluyentes de responsabilidad que pretendan impedir la investigación y sanción de los responsables de las violaciones graves de los derechos humanos tales como la tortura, las ejecuciones sumarias, extralegales o arbitrarias y las desapariciones

${ }^{85}$ Corte de Apelaciones de Rancagua, Rol No 103-2011, de 14 de enero de 2013, (considerando octavo). 
forzadas, todas ellas prohibidas por contravenir derechos inderogables reconocidos por el Derecho Internacional de los Derechos Humanos" ${ }^{86}$

"Como consecuencia de la manifiesta incompatibilidad entre las leyes de autoamnistía y la Convención Americana sobre Derechos Humanos, las mencionadas leyes carecen de efectos jurídicos y no pueden seguir representando un obstáculo para la investigación de los hechos que constituyen este caso ni para la identificación y el castigo de los responsables, ni puedan tener igual o similar impacto respecto de otros casos de violación de los derechos consagrados en la Convención Americana acontecidos en el Perú. CIDH" ${ }^{87}$

De acuerdo a lo dispuesto en el art. $2^{\circ}$ de la Convención, el Estado debe adoptar todas las medidas para dejar sin efecto las disposiciones legales que pudieran contravenirla. Por su parte, la $\mathrm{CIDH}$ ha declarado que las leyes de amnistía “carecen de efectos jurídicos”. Pero, ¿cuál es el alcance de esta declaración?, ¿cómo se hace efectiva?, ¿puede la Corte constituirse en un legislador negativo? Sabemos que las normas internas sólo pueden derogarse o dejarse sin efecto en virtud de otra ley, ya sea en forma expresa o tácita. Asimismo, en virtud del control de constitucionalidad a posteriori regulado en el artículo 93, número 7, de la Constitución Política, las normas declaradas inconstitucionales se entenderán derogadas desde la publicación en el Diario Oficial de la sentencia que acoja el reclamo, la que no producirá efecto retroactivo (art. 94, inciso tercero).

La vigencia de la ley es un tema de orden público interno que se regula a través de procedimientos claramente establecidos por nuestro ordenamiento jurídico, dentro de los cuales no encontramos comprendidas las sentencias de un tribunal internacional como mecanismo de derogación de las leyes. Entenderlo de esa forma sería conferir una competencia a la $\mathrm{CIDH}$ que no se ha contemplado constitucionalmente y vulneraría lo dispuesto en los arts. $5^{\circ}$ inciso primero, $6^{\circ} \mathrm{y}$ $7^{\circ}$ de nuestra Carta Fundamental.

El Decreto Ley No 2.191 es norma vigente en Chile y, en consecuencia, podría un juez eventualmente aplicarlo, sobre todo cuando se trata de crímenes que no quedan comprendidos dentro de la categoría de secuestro permanente. El problema que se ha suscitado entonces es cómo armonizar el fallo de la Corte con

${ }^{86} \mathrm{CIDH}$, Caso Barrios Altos vs. Perú, de 14 de marzo de 2001 (par. 41); CIDH, Caso de la Masacre de las Dos Erres vs. Guatemala, de 24 de noviembre de 2009 (par. 129): CIDH, Caso Gómes Lund y otros (Guerrilha do Araguaia) vs. Brasil, de 24 de noviembre de 2010 (par. 171); CIDH, Caso Almonacid Arellano vs. Chile, de 26 de septiembre de 2006.

${ }^{87}$ CIDH, Caso Barrios Altos vs. Perú, de 14 de marzo de 2001 (par. 44); CIDH, Caso Almonacid Arellano vs. Chile, de 26 de septiembre de 2006 (par. 119). 
nuestra realidad jurídica, a fin de dar cumplimiento a aquella medida de reparación consistente en asegurar que este decreto no siga representando un impedimento para las investigaciones y, en su caso, las sanciones de los responsables por graves violaciones a los derechos humanos.

a. Una posibilidad es entender que a la luz de lo dispuesto en el inciso segundo del artículo $5^{\circ}$ de la Constitución Política y en los tratados internacionales de Derecho Humanos, ratificados por Chile y que se encuentran vigentes ${ }^{88}$, el Decreto Ley No 2.191 se encontraría tácitamente derogado por ser incompatible con tales normas de rango superior y de vigencia posterior.

Esta es la vía que ha seguido Argentina. Así, en el caso "Simón Julio, del Cerro, Juan Antonio s/sustracción de menores de 10 años", el juez federal declaró inválido el artículo $1^{\circ}$ de la Ley No 23.492 y los artículos 1.3 y 4 de la Ley No 23.251 (Leyes de Punto Final y de Obediencia Debida) por incompatibilidad con los Pactos Internacionales de Derechos Humanos y procedió a declarar la inconstitucionalidad y la nulidad insanable de dichos artículos, en conformidad con el artículo 29 de la Constitución Nacional Argentina. Por su parte, la Corte Suprema de Uruguay falló de manera similar, en sentencia No 365 de 19 de octubre de 2009, haciendo lugar a la excepción de inconstitucionalidad interpuesta respecto a los artículos $1^{\circ}, 3^{\circ}$ y $4^{\circ}$ de la Ley $N^{o} 15.848$ que establecía la caducidad de la pretensión punitiva del Estado respecto de ciertos delitos cometidos durante la dictadura militar.

b. Otra Alternativa es la derogación formal del Decreto Ley No 2.191.

Se ha entendido por algunos, y al parecer éste también es el criterio de la Corte, que es necesario derogar el Decreto Ley No 2.191, pues su sola vigencia

${ }^{88}$ Convenios de Ginebra y sus Protocolos Adicionales; ratificado el 12 de octubre de 1950, promulgados por Decreto Supremo No 752, de 5 de diciembre de 1950; Convención para la Prevención y la Sanción del Delito de Genocidio, aprobada por Decreto Supremo No 316, de 5 de junio de 1953, del Ministerio de Relaciones Exteriores, publicado el 11 de diciembre de 1953; Convención de Naciones Unidas contra la Tortura y otros Tratamientos Crueles, Inhumanos y Degradantes, aprobada por Decreto Supremo No 808, de 7 de octubre de 1988, del Ministerio de Relaciones Exteriores, publicado el 26 de noviembre de 1988; Pacto Internacional de los Derechos Civiles y Políticos, promulgado por Decreto Supremo No 778, de fecha 30 de noviembre de 1976, del Ministerio de Relaciones Exteriores, publicado el 29 de abril de 1989; Convención de Viena sobre Derecho de los Tratados, promulgada por Decreto Supremo No 381, del Ministerio de Relaciones Exteriores, publicado el 22 de junio de 1981; Convención Interamericana sobre Desaparición Forzada de Personas, promulgada por decreto supremo del Ministerio de Relaciones Exteriores de fecha 27 de enero de 2010, publicado el 24 de febrero de 2010, y Estatuto de Roma, que crea la Corte Penal Internacional, promulgado por decreto supremo del Ministerio de Relaciones Exteriores de fecha 6 de julio de 2009, publicado el 1 de agosto de 2009. 
constituye per se una violación de la obligación de garantía, consagrada en el artículo 1.1 de la CADH.

En el Caso Velásquez Rodríguez vs. Honduras, la CIDH precisa el deber de garantía señalando:

"166. La segunda obligación de los Estados Partes es la de 'garantizar' el libre y pleno ejercicio de los derechos reconocidos en la Convención a toda persona sujeta a su jurisdicción. Esta obligación implica el deber de los Estados Partes de organizar todo el aparato gubernamental y, en general, todas las estructuras a través de las cuales se manifiesta el ejercicio del poder público, de manera tal que sean capaces de asegurar jurídicamente el libre y pleno ejercicio de los derechos humanos. Como consecuencia de esta obligación los Estados deben prevenir, investigar y sancionar toda violación de los derechos reconocidos por la Convención y procurar, además, el restablecimiento, si es posible, del derecho conculcado y, en su caso, la reparación de los daños producidos por la violación de los derechos humanos". ${ }^{89}$

Por su parte, en el Caso Barrios Altos vs. Perú, la Corte agrega que:

"La promulgación de una ley manifiestamente contraria a las obligaciones asumidas por un Estado parte en la Convención constituye per se una violación de ésta y genera responsabilidad internacional del Estado" ${ }^{90}$

Sin embargo, no se ha podido llegar a una solución efectiva en esta materia, ya que hay quienes sostienen que la derogación de la norma no zanja el problema pues, en virtud del principio constitucional de irretroactividad de la ley penal, debería respetarse su vigencia para los casos a los que aplica, en virtud de que es ley más favorable al reo (procesado o inculpado).

¿Qué medidas ha adoptado el Estado en esta materia?

Se puede analizar las medidas que ha ido adoptando el Estado en materia de amnistía para ajustar su ordenamiento jurídico a los estándares internacionales desde dos ámbitos o funciones públicas distintas: por un lado, los proyectos de ley que se han presentado en el Congreso para adecuar la legislación doméstica al orden internacional y, por otro lado, la evolución que ha experimentado la jurisprudencia de los tribunales en relación a la interpretación y aplicación (o no aplicación) del Decreto Ley de Amnistía.

89 CIDH, Caso Velásquez Rodríguez vs. Honduras, de 29 de julio de 1988 (par. 175).

90 CIDH, Caso Barrios Altos vs. Perú, Interpretación de la Sentencia de Fondo, de 3 de septiembre de 2001 (par. 18). 
a. Me referiré, en primer lugar, a los proyectos de ley en relación a la vigencia o interpretación de la amnistía:

A) Proyecto de Ley que interpreta el Decreto Ley No 2.191 de $1978 .^{91}$

Fue presentado en abril de 1992 por los senadores Rolando Calderón Aránguiz, Jaime Gazmuri Mujica, Ricardo Núñez Muñoz y Hernán Vodanovic Schnake. Tenía por objeto la dictación de una ley interpretativa del Decreto Ley No 2.191 que anulara los efectos de la amnistía en delitos que constituyen graves violaciones a los derechos humanos, en el sentido de aclarar que los delitos constitutivos de crímenes lesa humanidad son inaministiables e imprescriptibles, de conformidad con los tratados internacionales de derechos humanos, en especial con los Convenios de Ginebra del año 1949.

Partía de la base de que en Chile había existido un estado de guerra interna durante los primeros días del golpe militar, condición esencial para la aplicación del artículo $3^{\circ}$ común de los Convenios de Ginebra, que consagra la obligación internacional de los Estados Partes en orden a enjuiciar y castigar a los responsables de infracciones graves a ellos.

El proyecto referido proponía en lo principal:

Artículo Primero. Declárase interpretando los artículos $1^{\circ}$ y $3^{\circ}$ del Decreto Ley $N^{\circ} 2.191$, sobre amnistía, publicado el 19 de abril del año 1978, que el correcto sentido y alcance de estas disposiciones en relación con el efecto de extinguir la responsabilidad penal no favorecen en caso alguno, y consecuentemente no son aplicables, a los autores, cómplices $o$ encubridores de los delitos con resultado de muerte o lesiones graves y personas desaparecidas cometidos por funcionarios de las Fuerzas Armadas, de Orden y Seguridad, equiparados o asimilados, o que hubieren actuado por el Poder del Estado en cualquier forma o desde cargos de gobierno y que constituyen ilícitos penales de secuestro y sustracción de menores de ejecución permanente, aplicación de tormentos o violencias innecesarias con resultado de muerte o de lesiones graves y homicidio previsto en los artículos 141, 142, 150 y 391 del Código Penal y 330 del Código de Justicia Militar.

Artículo Segundo. En los casos previstos por el artículo anterior, y en que se hubiere decretado sobreseimiento definitivo ejecutoriado, en aplicación del Decreto Ley $N^{o} 2.191$ sobre amnistía, el Ministerio Público, los perjudicados y ofendidos por dichos delitos podrán recurrir, en el plazo de un año a partir de la publicación de esta ley, ante la Corte Suprema para que esta revise y anule dichas resoluciones por error de derecho al calificar e interpretar los artículos $1^{\circ}$ y $3^{\circ}$ del Decreto Ley $N^{\circ} 2.191$, en relación al artículo 408 No 5 del Código de Procedimiento Penal y 93 No 3 del Código Penal. ...Anuladas las

91 Boletín No 654-07, (fecha de consulta: 2 de noviembre de 2012). Disponible en http://www.camara.cl/ pley/pley_detalle.aspx?prmID=1781\&prmBL=654-07. 
resoluciones, la Corte Suprema ordenará reabrir los procesos remitiéndolos al Tribunal competente.

El proyecto fue archivado en mayo de 2001.

B) Proyecto de ley que Interpreta el Decreto Ley No 2.191, de 1978, de Amnistía, e introduce otras normas sobre la materia. ${ }^{92}$

Este proyecto fue iniciado por moción del senador Francisco Javier Errázuriz Talavera, fundado en la necesidad de lograr la reconciliación nacional. Proponía interpretar el Decreto Ley No 2.191 en el sentido de establecer que respecto de las conductas señaladas en su artículo $1^{\circ}$, y con expresa excepción de las que aparecen en sus artículos $3^{\circ}$ y $4^{\circ}$, se ha producido la extinción de la acción penal y no sólo de la pena, lo que impide iniciar nuevas investigaciones a su respecto y obliga a sobreseer definitivamente y sin más trámite a las que se hallaren pendientes sobre tales hechos. Sin embargo, se faculta al juez para continuar con las investigaciones (con carácter de reserva) con el objeto de determinar el paradero de estas personas o de sus cuerpos en caso de haber fallecido, y poder decretar la muerte presunta de ellas e incluso conceder la posesión definitiva de sus bienes en condiciones especiales.

El proyecto fue retirado por su autor en septiembre del mismo año y archivado.

C) Proyecto de ley que dicta normas para la aplicación de la amnistía, restringe la procedencia del sobreseimiento temporal, y establece un procedimiento judicial para determinar el paradero físico de las personas detenidas desaparecidas o de sus restos. ${ }^{93}$

Este proyecto fue iniciado por moción de los senadores Sergio Diez U., Hernán Larraín F., Miguel Otero L. y Sebastián Piñera E., el que parte observando que la aplicación procesal del Decreto Ley No 2.191 no ha sido uniforme por parte de nuestros tribunales, lo que atenta contra el principio de igualdad ante la ley y certeza jurídica.

En algunos casos se ha sobreseído inmediatamente después de establecido que el delito está comprendido en la ley y en otros casos se precisa primero determinar la persona de los culpables para, después, declarar la procedencia de la amnistía y sobreseer definitivamente. Como en Chile la jurisprudencia no obliga, cada juez

92 Boletín No 1.632-07, (fecha de consulta: 2 de noviembre de 2012). Disponible en http://www.camara. cl/pley/pley_detalle.aspx?prmID=1718\&prmBL=1632-07.

93 Boletín No 1.657-07, (fecha de consulta: 2 de noviembre de 2012). Disponible en http://www.camara. cl/pley/pley_detalle.aspx?prmID=596\&prmBL=1657-07. 
puede tener una opinión particular respecto de la interpretación y aplicación de una ley, no obstante que la Corte Suprema de Justicia, en fallos reiterados, haya mantenido una determinada opinión. Es por ello que el problema que origina una distinta forma de aplicar procesalmente una ley de amnistía no es materia de solución judicial, sino que es materia de carácter legislativo.

El proyecto proponía restringir la utilización del sobreseimiento temporal por falta de antecedentes para continuar la investigación a aquellas situaciones en que exista la expectativa razonable de que ello aparezca en el futuro, fijándose además un plazo de un año al cabo del cual el sobreseimiento temporal se transforma en definitivo si los antecedentes esperados no se presentan. Consideraba también establecer un procedimiento para que los jueces, no obstante haberse decretado el sobreseimiento, pudieran continuar con la investigación exclusivamente para determinar el paradero de las víctimas.

El proyecto fue archivado en junio de 2001.

D) Proyecto de ley que interpreta el Decreto Ley No 2.191 tratándose de delitos que el Derecho Internacional califica de lesa humanidad. ${ }^{94}$

Este proyecto fue iniciado por moción de los Senadores Ruiz De Giorgio y Ruiz Esquide sobre la base de una propuesta presentada por la Agrupación de Familiares de Detenidos Desaparecidos. Interpretaba los artículos $1^{\circ}$ y $3^{\circ} \mathrm{del}$ Decreto Ley No 2.191 en el sentido de que

"Estas disposiciones, en relación con el efecto de extinguir la responsabilidad penal, no favorecen en caso alguno, y consecuentemente no son aplicables, a los autores, cómplices o encubridores de los delitos que el Derecho Internacional, del cual el Estado de Chile es signatario, califica como de lesa humanidad: delito de secuestro y arresto ilegal con desaparecimiento, o muerte de la víctima, homicidio en cualquiera de sus formas, violencia innecesaria con resultado de muerte, cometidos por funcionario de las Fuerzas Armadas, de Orden y Seguridad, o civiles adscritos, equiparados o asimilados a estos cuerpos armados, o que hubieren actuado por el estado en cualquiera forma o desde cargos de gobierno y que constituyen ilícitos penales, previstos y sancionados en los artículos 141, 148 y 391 del Código Penal y $330 N^{\circ}$ 1, con la agravante contemplada en el inciso final de la misma disposición del Código de Justicia Militar". ${ }^{95}$

${ }^{4}$ Boletín No 1.718-07, (fecha de consulta: 2 de noviembre de 2012). Disponible en http://www.camara. cl/pley/pley_detalle.aspx?prmID=582\&prmBL=1718-07.

${ }_{95}$ Artículo $1^{\circ}$, Proyecto de Ley que Interpreta el Decreto Ley No 2.191, tratándose de delitos que el Derecho Internacional califica de lesa humanidad. Boletín No 1.718-07, (fecha de consulta: 2 de noviembre de 2012). Disponible en http://www.camara.cl/pley/pley_detalle.aspx?prmID=582\&prmBL=1718-07. 
El artículo segundo del proyecto de ley disponía:

"En esos delitos de lesa humanidad, señalados en el artículo anterior, tampoco se les aplicará la causal de extinción de la responsabilidad penal contemplada en el artículo No 93 del Código Penal".

Establecía también que debían reabrirse todos los procesos singularizados en los artículos $1^{\circ}$ y $3^{\circ}$ de esta ley, que se encontraren sobreseídos temporalmente y los que se hubieren sobreseído definitivamente por aplicación del Decreto Ley No 2.191 o del artículo 93 No 6 del Código Penal, por el solo ministerio de la ley volverían al estado de sumario, a fin de practicar diligencias con el propósito de localizar los restos de la víctima, por el ministro de la Corte de Apelaciones que se designe en conformidad a esta ley para su juzgamiento y fallo posterior.

El proyecto fue también archivado en julio del 2000.

E) Proyecto de ley que declara la nulidad de derecho público del Decreto Ley $N^{o} 2.191$ de 1978, señalando efectos que indica. ${ }^{96}$

Este proyecto de ley buscaba que se declarare la nulidad del Decreto Ley No 2.191 por carecer de los presupuestos materiales y formales necesarios para su legitimidad debiendo, en consecuencia, ser anulado y privado de efectos jurídicos, en conformidad a lo establecido por la CIDH. Se basaba en los siguientes argumentos: a) el Derecho Internacional ha sostenido que son inadmisibles las disposiciones de amnistía, las disposiciones de prescripción y el establecimiento de excluyentes de responsabilidad que pretendan impedir la investigación y sanción de los responsables de las violaciones graves de los derechos humanos; b) La $\mathrm{CIDH}$ ha dicho que las leyes de amnistía carecen de efectos jurídicos; c) según la $\mathrm{CADH}$ el Estado debe respetar y garantizar los derechos humanos, para lo cual precisa estructurar el aparato gubernamental de tal manera que sus instituciones sean capaces de asegurar la vigencia de los derechos humanos, lo cual incluye el deber de prevenir, investigar y sancionar toda violación de los derechos reconocidos por la Convención; d) los autores del Decreto Ley No 2.191 actuaron fuera del orden constitucional de manera que mal pueden invocar los principios constitucionales para defender su aplicación; e) el Decreto Ley No 2.191 vulnera el artículo $7^{\circ}$ de la Constitución y, en consecuencia, adolece de nulidad de derecho público; f) la nulidad de derecho público se produce de pleno derecho y no puede sanearse de manera alguna, ni siquiera por prescripción; g) respecto

96 Boletín No 4.162-07, (fecha de consulta: 2 de noviembre de 2012). Disponible en http://www.camara. cl/pley/pley_detalle.aspx?prmID=4555\&prmBL=4162-07. 
del argumento de la irretroactividad y ultractividad de la ley penal, no podría plantearse en este caso, ya que lo que propone el proyecto no es la derogación de la ley sino la nulidad de derecho público por el vicio contenido en esta apariencia de ley, lo cual trae como natural consecuencia retrotraerse al momento anterior a la dictación del acto ilegal e inconstitucional, es decir, considerar que el acto ilegal e inconstitucional nunca existió.

Este proyecto fue archivado en marzo de 2010.

F) Proyecto de ley que Interpreta el art. 93 del Código Penal, excluyendo de la extinción de la responsabilidad penal, por amnistía, indulto o prescripción, a los crimenes y simples delitos que constituyen genocidio, crimenes de lesa humanidad y de guerra, contemplados en los tratados internacionales ratificados por Chile y que se encuentran vigentes. ${ }^{97}$

Los objetivos de este proyecto eran: a) poner al día nuestro ordenamiento jurídico penal, en atención a los avances del Derecho Internacional en materia de Derechos Humanos, en cuanto a la inamnistiabilidad e imprescriptibilidad de los ilícitos que constituyen genocidio y crímenes de guerra y de lesa humanidad, y b) dar cumplimiento al fallo de la $\mathrm{CIDH}$ en orden a marginar de nuestro sistema el Decreto Ley de Amnistía.

Mediante un artículo único proponía:

"Artículo único.- Fijase el verdadero sentido y alcance de las causales de extinción de la responsabilidad penal que se establecen en el artículo 93 del Código Penal, en orden a que deberá entenderse que la amnistía, el indulto y la prescripción de la acción penal y de la pena no serán aplicables a los crímenes y simples delitos que constituyen genocidio, crimenes de lesa humanidad y de guerra, contemplados en los tratados internacionales ratificados por Chile y que se encuentran vigentes".

El proyecto fue archivado por rechazo general del proyecto en marzo de 2009.

b. Dentro de las otras medidas adoptadas por el Estado para adecuar el orden interno a lo dispuesto por la CIDH en sus sentencias encontramos la evolución que ha experimentado la jurisprudencia de los tribunales en esta materia, partiendo desde una aplicación irrestricta del decreto en sus primeros años hasta llegar a una inaplicación del mismo, fundada en los tratados internacionales de derechos humanos (en especial la CADH y los Convenios de Ginebra de 1949).

${ }^{97}$ Boletín No 5.918-07; (fecha de consulta: 2 de noviembre de 2012). Disponible en http://www.camara. cl/pley/pley_detalle.aspx?prmID=6302\&prmBL=5918-07. 
La Corte Suprema, en el caso del mirista Sandoval Rodríguez, ${ }^{98}$ concluyó que en los casos de desapariciones forzadas calificadas como secuestro permanente, el delito se sigue perpetrando mientras no se determine el paradero de la víctima, por lo que la Ley de Amnistía se torna inaplicable ya que el secuestro continuaba perpetrándose una vez que expiró el período de tiempo cubierto por esta causal de extinción de responsabilidad criminal.

"[E]l Estado de Chile se impuso, al suscribir y ratificar [tratados internacionales], la obligación de garantizar la seguridad de las personas [...], quedando vedadas las medidas tendientes a amparar los agravios cometidos contra personas determinadas o lograr la impunidad de sus autores, teniendo especialmente presente que los acuerdos internacionales deben cumplirse de buena fe. [Esa] Corte Suprema en reiteradas sentencias ha reconocido que la soberanía interna del Estado [...] reconoce su limite en los derechos que emanan de la naturaleza humana; valores que son superiores a toda norma que puedan disponer las autoridades del Estado, incluido el propio Poder Constituyente, lo que impide que sean desconocidos". 99

En otro fallo, ${ }^{100}$ la Corte Suprema invalidó la aplicación de la amnistía sosteniendo que el secuestro tiene el carácter de delito de lesa humanidad por lo cual es inamnistiable, de acuerdo a los Convenios y normas internacionales.

No obstante que los tribunales han ido inaplicando el Decreto Ley de Amnistía de manera uniforme y sostenida en el tiempo, la CIDH considera que aquello no da garantías suficientes de que el decreto no volverá a ser aplicado y considera a la sentencia en esta parte como no cumplida.

¿Qué solución se ha dado en el Derecho Comparado en relación a las leyes de autoamnistía?

Los Estados, han ido incorporando los estándares internacionales en las decisiones de sus tribunales y han ido adecuando sus ordenamientos jurídicos internos a lo dispuesto en las sentencias de la Corte a través de la ejecución inmediata del fallo de la Corte en el orden interno.

\footnotetext{
${ }^{98}$ Corte Suprema, Decisión del Pleno respecto de la instancia que verá la aplicación de la Ley de Amnistía en el caso del secuestro del mirista Miguel Angel Sandoval, Rol No 517-2004, de 17 de noviembre de 2004 (cons. 33). Citado por la CIDH, Caso Gelman vs. Uruguay, de 24 de febrero de 2011.

99 Corte Suprema, Caso del secuestro del mirista Miguel Ángel Sandoval, Rol No 517-2004, de 17 de noviembre de 2004 (cons. 35). Citado por la CIDH, Caso Gelman vs. Uruguay, de 24 de febrero de 2011.

100 Corte Suprema, Caso de Claudio Abdón Lecaros Carrasco seguido por el delito de secuestro calificado, Rol No 47.205, de 18 de mayo de 2010.
} 


\section{1) Argentina}

La Corte Suprema de Justicia de la Nación de Argentina resolvió, en el caso "Simón Julio, del Cerro, Juan Antonio s/sustracción de menores de 10 años", declarar inválido el artículo $1^{\circ}$ de la Ley No 23.492 y los artículos 1.3 y $4^{\circ}$ de la Ley No 23.251 (Leyes de Punto Final y de Obediencia Debida) por incompatibilidad de éstas con los Pactos Internacionales de Derechos Humanos al impedir la investigación, juzgamiento y eventual condena de hechos que implicaban violaciones a los derechos humanos, y procedió a declarar la inconstitucionalidad y la nulidad insanable de dichos artículos, en conformidad con el artículo 29 de la Constitución Nacional Argentina. ${ }^{101}$

2) Perú

En el caso Barrios Altos ${ }^{102}$, la CIDH declaró que las Leyes de Amnistía No 26.479 de junio de 1995 y No 26.492 (interpretativa de la anterior) son incompatibles con la CADH y, en consecuencia, carecen de efectos jurídicos, teniendo dicha decisión efectos generales. ${ }^{103}$

La Comisión solicitó a la Corte que ordenara al Estado derogar o dejar sin efecto las leyes No 26.479 y No 26.492 y así lo reiteró posteriormente en el caso "La Cantuta" 104 sosteniendo que "la existencia formal de las leyes de amnistía $N^{o} 26.479$ y No 26.492 dentro del ordenamiento jurídico peruano constituye per se un incumplimiento del artículo $2^{\circ}$ de la Convención. Este artículo, incluye la obligación positiva de los Estados de derogar la legislación que sea incompatible con su objeto y fin".

${ }^{101}$ Corte Suprema de Justicia de la Nación de Argentina, Caso Simón, Julio Héctor y otros s/privación ilegitima de la libertad, etc., Causa 17.768, de 14 de junio de 2005 (cons. 31). Asimismo, respecto del rol de los poderes legislativo y judicial en cuanto a la determinación de inconstitucionalidad de una ley, la Corte Suprema de la nación trasandina señaló que "considerada la Ley $N^{o} 25.779$ [que anuló las leyes de amnistías], desde una perspectiva formalista, podría ser tachada de inconstitucional, en la medida en que, al declarar la nulidad insanable de una ley, viola la división de poderes, al usurpar las facultades del Poder Judicial, que es el único órgano constitucionalmente facultado para declarar nulas las leyes o cualquier acto normativo con eficacia jurídica. [...] la solución que el Congreso considera que corresponde dar al caso, [...] en modo alguno priva a los jueces de la decisión final sobre el punto". Corte Suprema de Justicia de la Nación de Argentina. Caso Simón, Julio Héctor y otros s/privación ilegítima de la libertad, etc., Causa 17.768, de 14 de junio de 2005 (cons. 34). Citado por la CIDH, Caso Gelman vs. Uruguay, de 24 de febrero de 2011 (par. 216).

102 CIDH, Caso Barrios Altos vs. Perú, de 14 de marzo de 2001 (par. 41; 44).

${ }^{103} \mathrm{CIDH}$, Caso Barrios Altos vs. Perú, Interpretación de la Sentencia de Fondo, de 3 de septiembre de 2001.

${ }^{104}$ CIDH, Caso La Cantuta vs. Perú, de 29 de noviembre de 2006. 
Sin embargo, tanto los representantes de las víctimas como el Estado sostuvieron, en el caso La Cantuta ${ }^{105}$ que no era procedente anular, ni conveniente derogar, las leyes de amnistía; lo primero por no consagrarse en el orden interno la posibilidad de anular una ley, y lo segundo, porque sería reconocer que antes de la derogación de la ley ésta surtió efectos como tal, lo que no se condice con lo resuelto por la CIDH en el caso Barrios Altos, donde declaró carente de efectos jurídicos a las leyes en cuestión, las que, en consecuencia, sólo tenían apariencia de tales, pero no eran verdaderamente leyes. Por lo demás, la derogación de estas leyes operaría sin efecto retroactivo.

Por consiguiente, deben entenderse expulsadas del ordenamiento jurídico las leyes No 26.479 y No 26.492, no por vía legislativa, sino por medio de una medida de mayor valor normativo como es la sentencia de la Corte en el caso Barrios Altos.

Así, el Estado sostuvo que debe entenderse que se ha ajustado al deber contenido en el artículo $2^{\circ}$ de la CADH, esto es, adecuar la legislación interna al Derecho Internacional, a través de la adopción de una serie de medidas encaminadas a tales efectos y que no implican necesariamente la nulidad o derogación de las leyes cuestionadas, pero sí importan su expulsión del ordenamiento jurídico y la consiguiente adecuación del orden jurídico interno a la Convención. Entre éstas encontramos algunas decisiones de los tribunales penales peruanos ${ }^{106}$ en orden a

105 CIDH, Caso La Cantuta vs. Perú, de 29 de noviembre de 2006 (par. 163-164).

106 La excepción de amnistía interpuesta por Ángel Arturo Pino Díaz en la Causa Pedro Yauri Bustamante (Causa No 044-2002) fue declarada infundada por el Segundo Juzgado Penal Especializado el 20 de octubre de 2004, aludiendo expresamente al Caso Barrios Altos; en la misma causa el Segundo Juzgado Penal Especializado declaró la improcedencia de la excepción de amnistía deducida por Héctor Gamarra Mamani invocando el Caso Barrios Altos; en la misma causa el Quinto Juzgado Penal Especializado declaró infundada el 12 de noviembre de 2004 la excepción de amnistía promovida por José Enrique Ortiz Mantas; en el Caso El Frontón (Causa No 125-04) el Juez del Primer Juzgado Supraprovincial de Lima declaró infundada la excepción de amnistía interpuesta por los procesados. En la Causa Pedro Yauri Bustamante (Causa No 044-2002): la excepción de prescripción de la acción penal presentada por Máximo Humberto Cáceda Pedemonte fue declarada infundada el 24 de febrero de 2003 por el Fiscal Provincial Adjunto Especializado; en el Caso Acumulado Barrios Altos, La Cantuta, Pedro Yauri y El Santa la (Causa No 032-2001), el Quinto Juzgado Penal Especializado declaró el 30 de abril de 2003 infundada la excepción de prescripción solicitada por Shirley Sandra Rojas Castro; el Fiscal Provincial Penal de Lima declaró el 1 de octubre de 2003 infundada la excepción de prescripción presentada por Marco Flores Alván; la Juez Penal Titular Superior de Justicia de Lima declaró infundada la excepción de prescripción de la cosa juzgada aducida por Shirley Sandra Rojas Castro en decisión de 13 de diciembre de 2004. En la Causa Pedro Yauri Bustamante (Causa No 044-2002): el Segundo Juzgado Penal Especializado declaró infundada el 29 de octubre de 2004 la excepción de cosa juzgada presentada por Gabriel Orlando Vera Navarrete; en el Caso Acumulado Barrios Altos, La Cantuta, Pedro Yauri y El Santa la (Causa No 032- 
declarar infundadas las excepciones de amnistía, prescripción de la acción penal o cosa juzgada y la apertura por parte de estos tribunales de nuevas investigaciones penales para determinar la responsabilidad de los autores de estas violaciones a los derechos humanos. Por su parte, el Tribunal Constitucional del Perú reconoce los efectos vinculantes de las sentencias de la Corte y ha declara carente de efectos jurídicos a las leyes de amnistía (caso Martín Rivas de 29 de noviembre de 2005). Al carecer las leyes de amnistía de efectos jurídicos ab initio, son nulas también las resoluciones judiciales dictadas al amparo de éstas y, en consecuencia, no pueden producir el efecto de cosa juzgada.

Sobre la base de estas medidas adoptadas por el Estado, de las normas constitucionales y procesales vigentes (que permiten la incorporación de las sentencias internacionales como directamente aplicables y ejecutables a nivel interno ${ }^{107}$ ) y, no habiéndose acreditado por la Comisión hechos o situaciones que demuestren la persistencia de los efectos de las leyes de amnistía, la Corte concluyó que el Estado ha suprimido los efectos que en algún momento pudieron generar esas leyes. ${ }^{108}$

En consecuencia, en criterio de la Corte la obligación de garantía consagrada en el artículo $2^{\circ}$ de la Convención no se traduce necesariamente en la derogación de las leyes incompatibles con la Convención, sino que se puede considerar cumplida con la adopción de un conjunto de otras medidas que aseguren que dichas normas no tendrán aplicación ni seguirán representando un obstáculo para las investigaciones y sanciones correspondientes.

3) Uruguay

Es distinto el caso uruguayo, pues la Ley No 15.848 de 1986 (Ley de Caducidad) que establecía la caducidad de la pretensión punitiva del Estado, respecto de ciertos delitos cometidos durante la dictadura militar, fue aprobada por el órgano legislativo y respaldada por la ciudadanía en referéndum legislativo del año 1989 $y$, posteriormente, al rechazar una reforma constitucional que buscaba declarar la nulidad de la Ley de Caducidad. Por lo tanto, no se trata en este caso de una

2001) el Juez Penal Titular Superior de Justicia de Lima declaró infundada la excepción de cosa juzgada propuesta por Nelson Carvajal García el 7 de diciembre de 2004. Todas citadas por la CIDH, Caso La Cantuta vs. Perú, de 29 de noviembre de 2006 (par. 183).

107 Ley No 28.237, Código Procesal Constitucional, publicado el 31 de mayo de 2004, art. 15, y Ley No 27.775 "Regula el Procedimiento de ejecución de Sentencias emitidas por Tribunales Supranacionales".

${ }^{108}$ CIDH, Caso La Cantuta vs. Perú, de 29 de noviembre de 2006 (par. 187). 
ley autoimpuesta sino de una ley claramente emanada de la voluntad soberana del pueblo.

Sin embargo, estas expresiones de la voluntad soberana en orden a apoyar la vigencia de la Ley No 15.8948, no quita, en criterio de la CIDH, el carácter de ilegítima a una ley de amnistía que pretende dejar impunes las graves violaciones a los derechos humanos pues importan una trasgresión a los deberes contraídos por los Estados en virtud de la Convención.

"238. El hecho de que la Ley de Caducidad haya sido aprobada en un régimen democrático y aun ratificada o respaldada por la ciudadanía en dos ocasiones no le concede, automáticamente ni por si sola, legitimidad ante el Derecho Internacional. La participación de la ciudadanía con respecto a dicha Ley, utilizando procedimientos de ejercicio directo de la democracia -recurso de referéndum (párrafo $2^{\circ}$ del artículo 79 de la Constitución del Uruguay)-en 1989 y-plebiscito (literal A del artículo 331 de la Constitución del Uruguay) sobre un proyecto de reforma constitucional por el que se habrian declarado nulos los artículos $1^{\circ}$ a $4^{\circ}$ de la ley-el 25 de octubre del año 2009, se debe considerar, entonces, como hecho atribuible al Estado y generador, por tanto, de la responsabilidad internacional de aquél.

239. La sola existencia de un régimen democrático no garantiza, per se, el permanente respeto del Derecho Internacional, incluyendo al Derecho Internacional de los Derechos Humanos, lo cual ha sido asi considerado incluso por la propia Carta Democrática Interamericana ${ }^{109}$. La legitimación democrática de determinados hechos o actos en una sociedad está limitada por las normas y obligaciones internacionales de protección de los derechos humanos reconocidos en tratados como la Convención Americana..." ${ }_{110}$

En un fallo de singular trascendencia, la Suprema Corte de Justicia del Uruguay da un vuelco importante en su jurisprudencia con la sentencia No 365, de 19 de octubre de 2009, en la causa Sabalsagaray Curutchet Blanca Stela, al acoger la excepción de inconstitucionalidad interpuesta respecto a los arts. $1^{\circ}, 3^{\circ}$ y $4^{\circ}$ de la Ley No 15.848.

Para declarar la inconstitucionalidad de la Ley de Caducidad, la Suprema Corte de Justicia del Uruguay consideró, no sólo la norma constitucional, sino que además, y de manera muy novedosa para el Uruguay, los derechos contenidos en los instrumentos internacionales de Derechos Humanos, y el concepto de "bloque de constitucionalidad" o "bloque de derechos", entendiendo que los derechos humanos se integran a la Constitución por la vía del artículo 72 de la

109 Asamblea General de la OEA, Resolución AG/RES. 1 (XXVIII-E/01), de 11 de septiembre de 2001.

110 CIDH, Caso Gelman vs. Uruguay, de 24 de febrero de 2011 (par. 238-239). 
misma (en relación con el artículo 82), por tratarse de derechos inherentes a la dignidad humana que la comunidad internacional reconoce en tales pactos. ${ }^{111}$

\section{Caso Atala Riffo y Niñas vs. Chile}

La Corte impuso al Estado las siguientes medidas de reparación: a) brindar a las víctimas que así lo requieran la atención médica o psicológica gratuita, de forma inmediata, adecuada y efectiva, a través de sus instituciones públicas de salud, incluyendo la provisión de medicamentos y, en su caso, transporte y otros gastos estricta y directamente relacionados con el tratamiento ${ }^{112}$; b) como medida de satisfacción se impuso al Estado la obligación de publicar, en el plazo de seis meses (contados desde la notificación de la sentencia) por una sola vez, el resumen oficial de ésta, en el Diario Oficial y en un diario de amplia circulación nacional y, en su integridad, en un sitio web oficial del Gobierno. ${ }^{113}$ Esta medida se cumplió cabalmente al publicarse el resumen de la sentencia en el Diario Oficial, en la edición del 10 de septiembre de 2012 de "El Mercurio" y, el texto íntegro de la sentencia, en el sitio oficial del Ministerio de Justicia ${ }^{114}$; c) como otra medida de satisfacción se impuso al Estado el deber de realizar un acto público de reconocimiento de responsabilidad internacional por los hechos del presente caso, haciendo referencia a las violaciones de derechos humanos declaradas en el fallo, asegurando la participación de las víctimas que así lo deseen e invitando al evento a las organizaciones que las representaron en las instancias nacionales e internacionales. Se dejó entregada al Estado la definición de las autoridades estatales que deberían participar, las que en todo caso deberían ser de alto rango y estar presentes representantes del Poder Judicial. ${ }^{115}$ Esta medida se cumplió el 14 de diciembre de 2012, a través de un acto de desagravio de la jueza Karen Atala, que se llevó a efecto en el Salón O’Higgins del Ministerio de Relaciones Exteriores y en que estuvieron presentes diversas autoridades del Poder Ejecutivo y del Poder Judicial, entre ellos el Ministro de Justicia y el Presidente de la Corte Suprema. En el acto se dio cuenta de la vulneración por parte del Estado a los derechos a la igualdad y no discriminación, del derecho a

111 Suprema Corte de Justicia de Uruguay, Caso de Nibia Sabalsagaray Curutchet (cons. III.8, par. 15).

112 CIDH, Caso Atala Riffo y Niñas vs. Chile, Sentencia de 24 de febrero de 2012 (par. 254-255; 314).

$113 \mathrm{CIDH}$, Caso Atala Riffo y Niñas vs. Chile, Sentencia de 24 de febrero de 2012 (par. 259; 314).

114 Disponible en www.minjusticia.gob.cl.

115 CIDH, Caso Atala Riffo y Niñas vs. Chile, Sentencia de 24 de febrero de 2012 (par. 263-264; 314). 
la vida privada y del derecho de ser oídos ${ }^{116}$; d) pagar las cantidades fijadas en la sentencia por concepto de indemnización por daño material e inmaterial y por el reintegro de costas y gastos. Respecto de la indemnización por daño material, la Corte consideró sólo los gastos por atención médica y psicológica relacionados exclusivamente con las afectaciones sufridas por las violaciones declaradas en este caso, excluyendo los gastos relativos a atención médica recibida por la señora Atala con anterioridad al proceso de tuición ${ }^{117}$. En marzo de 2012 la Tesorería General de la República cursó la indemnización a favor de la señora Atala y sus hijas; e) como garantía de no repetición la Corte, reconociendo los avances del Estado en materia de programas de capacitación de funcionarios públicos, le impuso, sin embargo, el deber de continuar implementando, en un plazo razonable, programas y cursos permanentes de educación y capacitación dirigidos a funcionarios públicos a nivel regional y nacional y particularmente a funcionarios judiciales de todas las áreas y escalafones de la rama judicial. Estos programas deberán versar sobre: i) derechos humanos, orientación sexual y no discriminación; ii) protección de los derechos de la comunidad LGBTI, y iii) discriminación, superación de estereotipos de género en contra de la población LGTBI.

La Comisión Interamericana y los representantes de las víctimas habían solicitado a la Corte, como otra garantía de no repetición, la adopción de medidas de derecho interno (reformas y adecuación de leyes contra la discriminación), pero la defensa de Chile demostró que nuestra legislación no discrimina por opción sexual de los padres y que, por el contario, consagra y garantiza el derecho a la igualdad en nuestra Constitución Política, amparándolo con el recurso de protección consagrado en el artículo 20 de la misma. Sostuvo además que la decisión de la Corte Suprema en el caso Atala no supone una práctica constante y amparada en la ley (o en la falta de ésta) que permita a los tribunales interpretar las normas de tuición de manera discriminatoria respecto de la orientación sexual de los padres. ${ }^{118}$

La Corte no acogió la solicitud de la Comisión y de los representantes de las víctimas, pues no fue materia de este caso el análisis de una determinada

\footnotetext{
116 http://www.minjusticia.gob.cl/es/component/search/?searchword=sentencia+atala\&ordering=\&searchp hrase=all (fecha de consulta 14 de enero de 2012).

117 CIDH, Caso Atala Riffo y Niñas vs. Chile, Sentencia de 24 de febrero de 2012 (par. 294-299; 314).

118 CIDH, Caso Atala Riffo y Niñas vs. Chile, Sentencia de 24 de febrero de 2012 (par. 265, 275, 276).
} 
norma y su compatibilidad con la $\mathrm{CADH}$, por lo que no consideró necesario adecuar normas específicas de derecho interno a la Convención, pero recordó que todos los órganos de los Estados parte de la Convención, incluidos los jueces y demás órganos de la administración de justicia están obligados a ejercer ex oficio un control de convencionalidad entre las normas internas y las de la Convención, debiendo interpretar las normas y aplicar las garantías judiciales de acuerdo a los principios establecidos por la jurisprudencia de este Tribunal en este caso. ${ }^{119}$

Si bien la Corte declaró que la legislación chilena se ajusta a la Convención en materia de discriminación, el Estado consideró importante avanzar en las políticas antidiscriminación aprobando para ello la Ley No 20.609, de 24 de julio de 2012, que Establece Medidas Contra la Discriminación. También ha ido adoptado una serie de políticas públicas de lucha contra la discriminación para promover la integración social de personas y grupos vulnerables a la misma, incluyendo la orientación sexual como uno de los criterios de discriminación contemplados.

\section{Principales obstáculos Para el CUMPLimiento y EJECUCIÓN DE LOS FALLOS DE LA CORTE}

Se puede observar, en general, que se ha ido evolucionando hacia una cultura de cumplimiento y seguimiento de los fallos de la Corte. Sin embargo, son varias las causas que dificultan muchas veces ese cumplimiento, tales como las realidades sociales y económicas, razones de política interna de los Estados o la conformación política de los órganos representativos, que no permiten alcanzar las mayorías constitucionales para adoptar los cambios legislativos necesarios para adecuar los ordenamientos jurídicos internos a la $\mathrm{CADH}$ y al Derecho Internacional de los Derechos Humanos.

Así, algunos Estados han invocado la "inejecutabilidad" de los fallos de la Corte, ${ }^{120}$ para excepcionarse de su cumplimiento fundándose, ya en el concepto clásico estatocéntrico de soberanía, ya en la prescripción de la acción penal, en

119 CIDH, Caso Atala Riffo y Niñas vs. Chile, Sentencia de 24 de febrero de 2012 (par. 281-282).

120 Véase resolución de la Segunda Sala Penal Transitoria de la Corte Suprema del Perú de 14 de junio de 1999 que declara la inejecutabilidad de la sentencia de la CIDH en el caso Loayza Tamallo y resolución del Consejo Supremo de Justicia Militar del Perú, del 11 de junio de 1999, que declara la inejecutabilidad de la sentencia de la CIDH en el caso "Castillo Petruzzi y otros", citado por SAGÜÉs (2003). 
leyes de amnistía o en la institución de cosa juzgada de las sentencias internas, o bien, en la supremacía de sus normas constitucionales y en la autonomía del Poder Judicial. ${ }^{121}$

Este último es el caso de la República Bolivariana de Venezuela, que desde al año 2000 en adelante a través de algunas sentencias la Sala Constitucional del Tribunal Suprema de Justicia ha desconocido el Derecho Internacional de los Derechos Humanos, desestimando el efecto vinculante de las sentencias de la $\mathrm{CIDH}$ al realizar un control de constitucionalidad de las mismas, llegando incluso a denunciar la CADH. ${ }^{122}$

Recientemente el fallo de la Sala Penal Permanente de la Corte Suprema del Perú, de 20 de julio de 2012, ${ }^{123}$ se aparta de los criterios establecidos por la propia Corte Suprema, Tribunal Constitucional y la CIDH, declarando que los crímenes perpetrados por el Grupo Colina en la masacre de Barrios Altos no constituyen crímenes de lesa humanidad.

El problema planteado se agrava por el vacío que presenta la Convención al no contemplar un procedimiento coactivo para el cumplimiento y ejecución de las decisiones de la Corte.

Respecto de las instituciones de la prescripción, cosa juzgada y principio ne bis in idem, especialmente cuando la medida de reparación consiste en investigar $y$, en su caso, sancionar a los responsables de las graves violaciones a los derechos humanos, la Corte ha señalado reiteradamente que no son admisibles las disposiciones de amnistía, de prescripción y el establecimiento de excluyentes de responsabilidad que pretendan impedir la investigación y sanción de los responsables de violaciones a los derechos humanos tales como la tortura, ejecuciones sumarias, extralegales o arbitrarias y las desapariciones forzadas, todas las cuales se encuentran prohibidas por contravenir derechos inderogables reconocidos por el Derecho Internacional de los Derechos Humanos. ${ }^{124}$

\footnotetext{
121 Véase Cantos, José M., expediente 1307/2003 y Simón, Julio H. y otros (Corte Suprema, junio 14/2005), citado por GoZAÍnI (2006), pp. 351-353.

122 Sala Constitucional, Tribunal Supremo de Justicia de Venezuela, sentencia No 1.942/2003, Caso Rafael Chavero, contra el canon americano sobre leyes de desacato; y sentencia No 1939/2008 Caso Venezuela contra la CIDH que declara la inejecutabilidad del fallo de la Corte de 5 de agosto de 2008 y solicita al ejecutivo nacional proceda a denunciar la CADH, citado por MeIer (2011), pp. 339 y 352.

123 Sentencia Sala Penal Permanente de la Corte Suprema, de 20 de julio de 2012, en Recurso de Nulidad 4104-2010.

${ }_{124}$ CIDH, Caso Barrios Altos vs. Perú, de 14 de marzo de 2001 (par. 41 y 44); CIDH. Caso Almonacid Arellano vs. Chile, de 26 de septiembre de 2006 (par. 112).
} 
En lo que toca a la cosa juzgada y al principio ne bis in idem, la Corte ha dicho que éste no resulta aplicable cuando: a) el sobreseimiento o absolución del responsable de una violación a los derechos humanos ha tenido por objeto sustraer al acusado de su responsabilidad penal; b) el procedimiento no fue instruido con independencia e imparcialidad, o c) no hubo la intención real de someter al responsable a la acción de la justicia. Tal sentencia produce sólo una cosa juzgada "aparente" o "fraudulenta". ${ }^{125}$

Así lo sostuvo también, en su voto razonado, el juez Sergio García Ramírez, ${ }^{126}$ en el sentido que la sentencia es la culminación de una serie de actos procesales perfectamente regulados y sujetos a un orden garantista que configuran lo que conocemos como "debido proceso". Por lo tanto, el "debido proceso" constituye el cimiento de la sentencia, pero no hay debido proceso cuando no se respetan las garantías judiciales previstas en el artículo $8^{\circ}$ de la Convención Americana. Si no hay debido proceso no puede haber tampoco una verdadera sentencia ni cosa juzgada y tampoco puede configurarse el principio ne bis in idem.

\section{CONCLUSIONES}

Al ser Chile parte de Convención Americana de Derechos Humanos y haber reconocido competencia a la Corte Interamericana de Derechos Humanos, se ha obligado a promover, proteger y garantizar los derechos humanos, reconocidos tanto en su legislación interna como en la $\mathrm{CADH}$, a adoptar todas las medidas legislativas o de otro carácter necesarias para hacer efectivos tales derechos y, por último, a dar cumplimiento a las sentencias emanadas de la CIDH en todos los casos en que sea parte.

Podemos observar que en la mayoría de los casos el Estado ha podido ir dando cumplimiento a las sentencias de la Corte y a las medidas de reparación impuestas. Respecto de las medidas de publicación de las sentencias, pago de indemnizaciones, o actos de desagravio no se presentan mayores dificultades para su cumplimiento. Sin embargo, cuando estas medidas consisten en adoptar reformas constitucionales o cambios legislativos el tema se torna más complejo debido al imperativo de contar con las mayorías políticas constitucionales para adoptar los cambios jurídicos necesarios para adecuar el ordenamiento interno a las obligaciones internacionales.

125 CIDH, Caso Almonacid Arellano vs. Chile, de 26 de septiembre de 2006 (par. 154).

126 CIDH, Caso La Cantuta vs. Perú, de 29 de noviembre de 2006, voto razonado juez Sergio García Ramírez (par.13). 
Los casos "Última Tentación de Cristo", Palamara Iribarne y Claude Reyes significaron la adopción de reformas constitucionales (supresión de la censura) y la aprobación de leyes, tales como la Ley de Transparencia y las reformas al Código de Justicia Militar. Sin embargo, del análisis de las discusiones legislativas se observa que muchas veces los criterios que emanan de las sentencias de la $\mathrm{CIDH}$, o no son considerados, o son considerados como meras recomendaciones, olvidando el carácter obligatorio de las mismas. Muchas veces las motivaciones de estos cambios legislativo obedecen más que al imperativo de dar cumplimiento a las obligaciones internacionales, a factores internos complejos, como fue el caso de la reforma a la competencia de la Justicia Militar, motivada por el conflicto puntual de la huelga de hambre de los comuneros mapuches que exigían el traspaso del conocimiento de sus causas desde la Justicia Militar a la Justicia Ordinaria.

En consecuencia, es posible concluir que el gran obstáculo para el Estado en cuanto al cumplimiento de las sentencias de la Corte, lo constituye muchas veces la falta de voluntad política para adoptar las medidas legislativas necesarias para adecuar el ordenamiento jurídico nacional a la CADH y al Derecho Internacional de los Derechos Humanos, así como la falta de una normativa interna que regule un procedimiento de cumplimiento y ejecución en el orden interno de las sentencias emanadas de la Corte Interamericana. Esto último reviste especial interés al no estar aún resuelto expresamente en nuestro ordenamiento jurídico, así como tampoco en la doctrina y jurisprudencia constitucional, el valor jerárquico que ocupan las normas del Derecho Internacional de los Derechos Humanos en el orden interno

Al respecto, y fruto del trabajo de un conjunto de destacados profesores chilenos de Derecho Constitucional y Procesal, se presentó al Congreso Nacional en el mes de octubre del año 2001 un proyecto de ley sobre acciones constitucionales de amparo o habeas corpus y protección ${ }^{127}$ donde se contempla un procedimiento de cumplimiento y ejecución de las sentencias emanadas de la CIDH, a través de la Corte Suprema de Justicia, proyecto que se encuentra, sin embargo, detenido en el Congreso desde el año 2008.

En materia de cumplimiento de las sentencias de la $\mathrm{CIDH}$ tenemos aún pendiente la revisión íntegra a la Justicia Militar para adecuarla a los estándares internacionales, y la adopción de medidas efectivas que aseguren que el Decreto

127 Boletín No 2.809-07; (fecha de consulta: 19 de noviembre de 2012). Disponible en http://www.camara. cl/pley/pley_detalle.aspx?prmID=3097\&prmBL=2809-07. 
Ley No 2.191 no volverá a constituir un obstáculo para la investigación de las violaciones a los derechos humanos y para perseguir la responsabilidad de quienes corresponda, la vigencia del delito de amenazas y desacato y su adecuación a los estándares internacionales.

Por el momento corresponderá a los jueces nacionales conducirse como jueces internacionales, al conocer, interpretar y aplicar las normas internacionales con el objeto de evitar hacer incurrir al Estado en nuevas responsabilidades internacionales.

\section{BibLIOGRAFía}

GozAíni, Osvaldo A. (2006): "Incidencia de la Sentencia de la Corte Interamericana de Derechos Humanos en el Derecho Interno", en Revista de Estudios Constitucionales, (Año 4, No 2), pp. 351-353.

MeIEr G., Eduardo (2011): "Nacionalismo Constitucional y Derecho Internacional de los Derechos Humanos", en Revista de Estudios Constitucionales, (Año 9, No 2), pp. 329-375.

SAGÜÉs, Néstor P. (2003): "Las Relaciones entre los Tribunales Internacionales y los Tribunales Nacionales en Materia de Derechos Humanos. Experiencias en Latinoamérica”, en Revista Ius et Praxis, (V. 9, No 1), pp. 205-221.

\section{Jurisprudencia}

Velásquez Rodríguez vs. Honduras (1988): CIDH 29 de julio de 1988.

Olmedo Bustos y otros vs. Chile (2001): CIDH 5 de febrero de 2001 (Fondo, Reparaciones y Costas). Serie C No 73.

Barrios Altos vs. Perú (2001): CIDH 14 de marzo de 2001 (Fondo). Serie C No 75.

19 Comerciantes vs. Colombia (2004): CIDH 5 de julio de 2004. Serie C No 109.

Lori Berenson Mejía vs. Perú (2004): CIDH 25 de noviembre de 2004. Serie C No 119.

Caso Simón, Julio Héctor y otros s/privación ilegitima de la libertad, etc. (2005): Corte Suprema de Justicia de la Nación Argentina, Causa 17.768, de 14 de junio de 2005.

Masacre de Mapiripán vs. Colombia (2005): CIDH 15 de septiembre de 2005. 
Palamara Iribarne vs. Chile (2005): CIDH 22 de noviembre de 2005 (Fondo, Reparaciones y Costas). Serie C No 135.

Claude Reyes y otros vs. Chile (2006): CIDH 19 de septiembre de 2006 (Fondo, Reparaciones y Costas). Serie C No 151.

Almonacid Arellano vs Chile (2006): CIDH 26 de septiembre de 2006 (Excepciones Preliminares, Fondo, Reparaciones y Costas). Serie C No 154.

La Cantuta vs. Perú (2006): CIDH 29 de noviembre de 2006 (Fondo, Reparaciones y Costas). Serie C. No 162.

Masacre de las Dos Erres vs. Guatemala (2009): CIDH 24 de noviembre de 2009.

Claudio Abdón Lecaros Carrasco seguido por el delito de secuestro calificado (2010): Corte Suprema, Rol No 47205, Recurso No 3302/2009, Resolución No 16698, Sentencia de Apelación, y Resolución No 16699, Sentencia de Reemplazo, de 18 de mayo de 2010.

Gomes Lund y otros (Guerrilha do Araguaia) vs. Brasil (2010): CIDH 24 de noviembre de 2010.

Gelman vs. Uruguay (2011): CIDH 24 de febrero de 2011. Serie C No 221.

Corte de Apelaciones de Rancagua, Rol No 103-2011, de 18 de octubre de 2011.

Corte de Apelaciones de Rancagua, Rol No 103-2011, 14 de enero de 2013.

Corte de Apelaciones de Rancagua, 1a Fiscalía de Rancagua, Rol No 103-2011, de 29 de noviembre de 2011.

Informe $1^{\text {a }}$ Fiscalía de Rancagua, de 29 de noviembre de 2011 http://corte. poderjudicial.cl/SITCORTEPORWEB/ (fecha de consulta: 2 de noviembre de 2012).

Atala Riffo y Niñas vs. Chile (2012): CIDH 24 de febrero de 2012 (Fondo, Reparaciones y Costas). Serie C No 239.

\section{Antecedentes Legislativos}

Cámara de Diputados, Discusión en Sala, Legislatura 341, Sesión 17, de 17 de noviembre de 1999, (fecha de consulta: 2 de noviembre de 2012). Disponible en http://www.leychile.cl/Navegar?idNorma=242302\&eh=True.

Senado. Legislatura 343, Sesión 40, de 02 de mayo de 2001, (fecha de consulta: 2 de noviembre de 2012). Disponible en http://www.leychile.cl/ Navegar?idNorma $=242302 \&$ eh $=$ True. 
Dictamen No 049883 de 4 de octubre de 2004, (fecha de consulta: 2 de noviembre de 2012). Disponible en http://www.leychile.cl/Consulta/portada_hl?tipo_ norma $=X X 1 \&$ nro_ley=20285\&anio=2012.

Cámara de Diputados, Legislatura 352, Sesión 79, de 18 de mayo de 2005, (fecha de consulta: 2 de noviembre de 2012). Disponible en http://www.leychile.cl/ Navegar?idNorma $=242302 \&$ eh $=$ True.

Cámara de Diputados, Legislatura 358, Sesión 82, de 30 de septiembre de 2010, (fecha de consulta: 2 de noviembre de 2012). Disponible en http://www. leychile.cl/Navegar?idNorma $=1021613$.

Oficio de la Corte Suprema a la Cámara de Diputados No 276, de 7 de diciembre de 2009.

Boletín No 6.734-02, (fecha de consulta: 2 de noviembre de 2012). Disponible en http://www.camara.cl/pley/pley_detalle.aspx?prmID=7128\&prmBL=673402.

Boletín No 6.739-02, (fecha de consulta: 2 de noviembre de 2012). Disponible en http://www.camara.cl/pley/pley_detalle.aspx?prmID=7134\&prmBL=673902.

Boletín No 7.203-02, (fecha de consulta: 2 de noviembre de 2012). Disponible en http://www.camara.cl/pley/pley_detalle.aspx?prmID=7602\&prmBL=720302.

Boletín No 654-07, (fecha de consulta: 2 de noviembre de 2012). Disponible en http://www.camara.cl/pley/pley_detalle.aspx?prmID=1781\&prmBL=65407.

Boletín No 1.632-07, (fecha de consulta: 2 de noviembre de 2012). Disponible en http://www.camara.cl/pley/pley_detalle.aspx?prmID=1718\&prmBL=163207.

Boletín No 1.657-07, (fecha de consulta: 2 de noviembre de 2012). Disponible en http://www.camara.cl/pley/pley_detalle.aspx?prmID=596\&prmBL=165707.

Boletín No 1.718-07, (fecha de consulta: 2 de noviembre de 2012). Disponible en http://www.camara.cl/pley/pley_detalle.aspx?prmID=582\&prmBL=171807.

Boletín No 4.162-07, (fecha de consulta: 2 de noviembre de 2012). Disponible en http://www.camara.cl/pley/pley_detalle.aspx?prmID $=4555 \& \mathrm{prmBL}=4162$ 07. 
Boletín No 5.159-07, (fecha de consulta: 2 de noviembre de 2012). Disponible en http://www.camara.cl/pley/pley_detalle.aspx?prmID=5542\&prmBL=515907.

Boletín No 5.918-07; (fecha de consulta: 2 de noviembre de 2012). Disponible en http://www.camara.cl/pley/pley_detalle.aspx?prmID=6302\&prmBL=591807.

Boletín No 2.809-07; (fecha de consulta: 19 de noviembre de 2012). Disponible en http://www.camara.cl/pley/pley_detalle.aspx?prmID=3097\&prmBL=280907.

www.minjusticia.gob.cl 